\title{
ЗАПИСИ МЕСТНЫХ ЗЕМЛЕТРЯСЕНИЙ КАК ОСНОВА ДЛЯ КОРРЕКТНЫХ ОЦЕНОК СЕЙСМИЧЕСКИХ ВОЗДЕЙСТВИЙ (НА ПРИМЕРЕ ТРАССЫ ВТОРОГО СЕВЕРОМУЙСКОГО ТОННЕЛЯ)
}

Павленко О. В.

\begin{abstract}
Аннотация
Для получения реалистичных и корректных оценок сейсмических воздействий на трассе строительства второго Северомуйского тоннеля исследуются записи местных землетрясений, полученные сейсмостанцией «Северомуйск» (SVKR) в 2005-2010 гг. (магнитуды mb 4.2-5.5, гипоцентральные расстояния $\mathrm{r}$ 15-220 км). Методами стохастического моделирования получены оценки региональных характеристик излучения и распространения сейсмических волн в северовосточной Бурятии: сброшенного напряжения ㅁ, форм очаговых спектров, ослабления волн на высоких частотах (каппа ए), параметров, определяющих форму и длительность акселерограмм и других. Предварительно оценено изменение длительности сильных движений в зависимости от эпицентрального расстояния, по скоростному разрезу получены оценки локального усиления А(f)

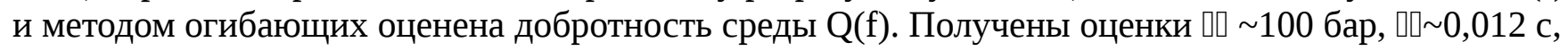
$\mathrm{Q}(\mathrm{f})$ в виде $\sim 60 \mathrm{f} 1.05$ для r $\sim 15-30$ км, $\sim 80$ f 1.0 для r $\sim 40-60$ км, $\sim 90$ f 0.9 для r $\sim 100-110$ км и $\sim 150 \mathrm{f}$ 0.7 для r $\sim 160-220$ км; геометрическое расхождение в виде трехсегментной функции $1 / \mathrm{r}$ для r $<50$ км, 1/50 для 50150 км; длительность в виде трехсегментной функции 0 для 050 км. Эти оценки могут использоваться для прогноза параметров колебаний поверхности при возможных в будущем сильных землетрясениях в регионе.
\end{abstract}

\section{Ключевые слова:}

стохастическое моделирование, параметр напряжений, добротность, геометрическое расхождение, локальное усиление, местные землетрясения 


\title{
ЗАПИСИ МЕСТНЫХ ЗЕМЛЕТРЯСЕНИЙ КАК ОСНОВА ДЛЯ КОРРЕКТНЫХ ОЦЕНОК СЕЙСМИЧЕСКИХ ВОЗДЕЙСТВИЙ (НА ПРИМЕРЕ ТРАССЫ ВТОРОГО СЕВЕРОМУЙСКОГО ТОННЕЛЯ)
}

\author{
О.В. Павленко \\ Институт физики Земли им. О.Ю. Шмидта РАН, г. Москва 123242, ул. Б. Грузинская, д. \\ 10, cmp. 1
}

Для получения реалистичных и корректных оценок сейсмических воздействий на трассе строительства второго Северомуйского тоннеля исследуются записи местных землетрясений, полученные сейсмостанцией «Северомуйск» (SVKR) в 2005-2010 гг. (магнитуды $m_{b} \sim 4.2-5.5$, гипоцентральные расстояния $r \sim 15-220$ км). Методами стохастического моделирования получены оценки региональных характеристик излучения и распространения сейсмических волн в северо-восточной Бурятии: сброшенного напряжения $\Delta \sigma$, форм очаговых спектров, ослабления волн на высоких частотах (каппа $\kappa$ ), параметров, определяющих форму и длительность акселерограмм и других. Предварительно оценено изменение длительности сильных движений в зависимости от эпицентрального расстояния, по скоростному разрезу получены оценки локального усиления $A(f)$ и методом огибающих оценена добротность среды $Q(f)$. Получены оценки $\Delta \sigma \sim 100$ бар, $\kappa \sim 0,012$ с, $Q(f)$ в виде $\sim 60 f^{1.05}$ для $r \sim 15-30$ км, $\sim 80 f^{1.0}$ для $r \sim 40-60$ км, $\sim 90 f$ 0.9 для $r \sim 100-110$ км и $\sim 150 f^{0.7}$ для $r \sim 160-220$ км; геометрическое расхождение в виде трехсегментной функции $1 / r$ для $r<50$ км, 1/50 для $50<r<150$ км и $1 / r^{0.5}$ для $r>150$ км; длительность в виде трехсегментной функции 0 для $0<r<5$ км, $0.222 r$ для $5<r<50$ км и $10+0.015 r$ для $r>50$ км. Эти оценки могут использоваться для прогноза параметров колебаний поверхности при возможных в будущем сильных землетрясениях в регионе.

Стохастическое моделирование, параметр напряжений, добротность, геометрическое расхождение, локальное усиление, длительность сильных движений, отклик грунта, местные землетрясения

\section{RECORDS OF LOCAL EARTHQUAKES AS A BASIS FOR CORRECT ESTIMATION OF STRONG GROUND MOTION (THE AREA OF THE SECOND SEVEROMUISK TUNNEL) O. V. Pavlenko \\ Schmidt Institute of Physics of the Earth, Russian Academy of Sciences, Moscow}

To obtain realistic and correct estimates of strong ground motion in the area of construction of the second Severomuisk tunnel, the records of local earthquakes obtained by "Severomuisk" seismic station (SVKR) in 2005-2010 are studied (magnitudes $m_{b} \sim 4.2-5.5$, hypocentral distances $r \sim 15-220 \mathrm{~km}$ ). Stochastic simulation methods are used to estimate regional characteristics of radiation and propagation of seismic waves in the North-Eastern Buryatia: the stress parameter $\Delta \sigma$, the shapes of source spectra, the wave attenuation at high frequencies kappa $\kappa$, parameters defining the shapes and durations of the acceleration time histories and others. Beforehand, the duration of strong motion as a function of the hypocentral distance was estimated from the records, local site amplification $A(f)$ was estimated based on the 
velocity structure of the region, and the envelope method was applied to estimate the quality function $Q(f)$. The following estimates are obtained: $\Delta \sigma \sim 100$ bars, $\kappa \sim 0,012 \mathrm{c}, Q(f)$ in the form $\sim 60 f^{1.05}$ for $r \sim 15-30 \mathrm{~km}, \sim 80 f^{1.0}$ for $r \sim 40-60 \mathrm{~km}, \sim 90 f^{0.9}$ for $r \sim 100-110 \mathrm{~km}$, and $\sim 150 f^{0.7}$ for $r \sim 160-220 \mathrm{~km}$; the geometrical spreading in the form $1 / r$ for $r<50 \mathrm{~km}, 1 / 50$ for $50<r<150 \mathrm{~km}$, and $1 / r^{0.5}$ for $r>150 \mathrm{~km}$; the duration in the form 0 for $0<r<5 \mathrm{~km}, 0.222 r$ for $5<r<50 \mathrm{~km}$ and $10+0.015 r$ for $r>50 \mathrm{~km}$. These estimates can be used to predict ground motion parameters in future strong earthquakes in the region.

Stochastic simulation, stress parameter, quality factor, geometrical spreading, local site amplification, duration of strong ground motion, soil response

\section{ВВЕДЕНИЕ}

При проектировании и строительстве сейсмостойких конструкций в сейсмических районах необходимы оценки параметров колебаний поверхности при возможных в будущем сильных землетрясениях: интенсивности, пиковых ускорений (PGA - в международной терминологии) и скоростей, спектров реакции, продолжительности и преобладающих периодов колебаний. Эти параметры требуется оценить для конкретных грунтовых условий, на поверхности грунта. В последние десятилетия заметно растет число строящихся сложных и дорогостоящих объектов, и от сейсмологов требуются оценки параметров колебаний поверхности с наибольшей возможной точностью.

$\mathrm{K}$ настоящему времени в сейсмологии разработаны надежные методы оценки параметров колебаний поверхности. Основой для этого служат записи землетрясений, полученные в регионе. Если имеется достаточно большое количество записей, для региона выводятся уравнения прогнозных движений грунта (УПДГ), которые и дадут необходимые оценки. Достаточное количество данных для разработки региональных УПДГ накоплено в Курило-Камчатском регионе.

Курило-Камчатская сейсмическая зона активно изучается в последние годы: исследуются особенности очаговых спектров [Гусев, 1993], оцениваются параметры распространения сейсмических волн: добротность и геометрическое расхождение [Abubakirov, Gusev, 1990], отклик грунтовых толщ [Pavlenko, 2013]. Достаточное количество записей сильных движений, полученных в регионе, позволяет вывести УПДГ и прогнозировать параметры колебаний поверхности при будущих сильных землетрясениях.

Другие регионы России с высокой сейсмичностью: Северный Кавказ, АлтаеСаянский регион, Байкальская рифтовая зона, Приморский край, Сахалин, Магаданская область, Якутия, Чукотка, - пока остаются менее изученными в сейсмическом плане.

В регионах, где получено лишь небольшое количество записей сильных движений, недостаточное для разработки региональных УПДГ, применяется другой подход: по имеющимся записям землетрясений оцениваются региональные характеристики излучения и распространения сейсмических волн, которые затем используются для построения акселерограмм возможных в будущем сильных землетрясений [Halldorsson, Papageorgiou, 2005]. По акселерограммам оцениваются необходимые в сейсмостойком строительстве параметры колебаний поверхности [Aki, Irikura, 1991]. С накоплением записей сильных движений в регионе появляется возможность уточнять характеристики излучения и распространения сейсмических волн и повышать точность прогноза параметров колебаний поверхности при будущих сильных землетрясениях. 
Такой подход использовался для оценки параметров излучения и распространения сейсмических волн на Северном Кавказе [Павленко, 2008, 2009, 2016], в Бурятии [Павленко, Тубанов, 2017], в северной Финляндии [Pavlenko, Kozlovskaya, 2018], в АлтаеСаянском регионе [Еманов и др., 2019].

В настоящей работе изучаются области северо-восточной Бурятии, Становое нагорье. Исследование характеристик излучения и распространения сейсмических волн в этом районе требуется для оценки сейсмической опасности в связи со строительством второго Северомуйского тоннеля.

Это опасный в сейсмическом плане регион, где в прошлом происходили сильные землетрясения, что отражено в картах общего сейсмического районирования территории РФ. Согласно действующим картам ОСР-2015, для периодов повторяемости 500 и 1000 лет район характеризуется сейсмической интенсивностью 9 баллов шкалы MCK-64, для периода повторяемости 5000 лет - 10 баллов. В ближайшей окрестности трассы тоннеля возможны землетрясения с максимальными магнитудами 7.5, согласно картам ОСР, причем один из сейсмогенных линеаментов пересекает трассу тоннеля. Для прогноза сейсмической опасности надежные оценки региональных параметров излучения и распространения сейсмических волн необходимы.

\section{МЕТОД И ДАННЫЕ}

Параметры излучения и распространения сейсмических волн оцениваются методами решения обратных задач: моделированием записей зарегистрированных местных землетрясений и подбором параметров, дающих наилучшее согласие зарегистрированных и смоделированных акселерограмм.

Для построения акселерограмм землетрясений применяется стохастический метод [Boore, 2003]. Достаточно простой, но эффективный стохастический подход основан на представлениях, подтверждаемых наблюдениями, о том, что акселерограммы в окнах вступлений $S$-волн представляют собой ограниченный по спектру Гауссовский белый шум. Частотные ограничения определяются граничной частотой спектра $f_{0}$ и частотой $f_{\max }-$ наивысшей частотой, определяемой регистрирующим прибором или затуханием в земной коре [Hanks, McGuirre, 1981]. Как показывает практика, в смоделированных акселерограммах мы получаем адекватное представление высокочастотных составляющих колебаний ( $f>0,1$ Гц), наиболее интересных для инженерной сейсмологии. Используя стохастический подход, можно с достаточно хорошей точностью моделировать сильные движения по записям слабых, поэтому метод широко применяется для расчетов в сейсмичных районах, где не имеется записей сильных землетрясений. Метод успешно применялся для расчетов параметров колебаний при землетрясениях с сейсмическими моментами в диапазоне более 12 порядков в различных тектонических условиях [Boore, 2003].

Входные данные расчетных программ - параметры, описывающие особенности излучения (эффекты очагов) и распространения (эффекты пути распространения) сейсмических волн в данном регионе, а также параметры, описывающие локальные эффекты вблизи источников и приемников. K входным параметрам относятся: средняя плотность земной коры и средняя скорость $S$-волн в коре в окрестности очага (локальные условия вблизи очага), сброшенное в очаге напряжение (эффект очага), параметры геометрического расхождения и частотно-зависимого неупругого поглощения сейсмических волн, зависимость длительности сейсмического сигнала от эпицентрального 
расстояния (эффекты пути), локальное усиление и ослабление сигнала на высоких частотах каппа (локальные условия вблизи приемника), параметры, определяющие волновые формы акселерограмм. Перечисленные параметры определяют рассчитанные акселерограммы на скале, т.е. без учета отклика грунта; при наличии грунтовой толщи эти акселерограммы пересчитываются в акселерограммы на поверхности грунта.

Для оценивания параметров излучения и распространения сейсмических волн в районе трассы второго Северомуйского тоннеля имеются 16 записей местных землетрясений, полученных сейсмостанцией «Северомуйск» SVKR (координаты 56.159 ${ }^{\circ}$ с.ш., $\quad 113.52^{\circ}$ в.д.) в 2005-2010 годах. Регистрация землетрясений велась сейсмоприемниками СМ-3 (Россия). В таблице 1 приведен каталог землетрясений, а на рисунке 1 показана карта расположения эпицентров. Координаты и глубины очагов $h$ землетрясений приводятся в соответствии с данными ISC (International Seismological Center). Магнитуды приведены в двух вариантах: в соответствии с ISC и в соответствии с данными Российской Геофизической Службы (в скобках). Магнитуды изучаемых землетрясений лежат в диапазоне $m_{b} \sim 4.2-5.5$, гипоцентральные расстояния $r$ изменяются от 15,6 до 219 км, глубины очагов $h$ - от 1,5 до 21,8 км (табл. 1).

При расчете акселерограмм стохастическим методом амплитуды колебаний рассчитываются как детерминированные функции со случайным фазовым спектром, а интенсивность и продолжительность колебаний задаются в зависимости от магнитуды землетрясения и расстояния до источника. Источник предполагается точечным, и поскольку исследуются записи достаточно слабых землетрясений (табл. 1), приближения точечных очагов допустимы. В расчетах использовалась программа D. Boore SMSIM, модифицированная (дополненная) автором для учета грунтовых условий. Сравнивались рассчитанные и зарегистрированные акселерограммы, а также их спектры, и подбирались входные параметры стохастического моделирования, позволяющие достичь наилучшего согласия расчетов и наблюдений во временной и спектральной областях. Согласие расчетов и наблюдений оценивалось по отклонениям пиковых ускорений и интенсивностей рассчитанных акселерограмм от зарегистрированных и по среднеквадратичным отклонениям спектральных амплитуд.

Предварительно методом огибающих были получены оценки добротности коры и верхней мантии в окрестностях Северомуйска. Метод огибающих описан в работе [Aki, Chouet, 1975], где авторы с использованием модели однократного рассеяния получили выражение для спадающих со временем спектральных амплитуд кода-волн $A(\omega \mid t)$ в диапазоне частот $\Delta f$ :

$$
\ln (A(\omega \mid t) \cdot t)=C-b t
$$

где $C$ - константа, зависящая от очагового спектра, $b=\pi f / Q_{c}$. Так, отфильтровав велосиграммы полосовым фильтром в окрестностях каждой из исследуемых частот и построив линейную регрессию (1) по огибающим амплитуд кода-волн, находим угловые коэффициенты $b$ и получаем оценки добротности $Q_{c}(f)$. С помощью метода огибающих по записям местных землетрясений были впервые получены оценки добротности в центральной Японии и определены свойства функции добротности - ее рост с частотой и изменчивость от региона к региону [Aki, Chouet, 1975]. Кода-волны на частотах 1 Гц считаются результатом рассеяния волн на приповерхностных неоднородностях, тогда как на высоких частотах кода-волны представляют собой результат рассеяния волн в глубокой высокодобротной литосфере. 
Метод огибающих подробно описан в работе [Добрынина и др., 2011], где он применен для оценивания добротности литосферы юго-западного фланга Байкальской рифтовой системы. В настоящей работе оценки добротности $Q(f)$ получены для гипоцентральных расстояний $r \sim 15-110$ км; записи землетрясений с бОльшими гипоцентральными расстояниями, $r \sim 160-220$ км, обрезаны по времени, т.е. не включают кода-волны, поэтому нет возможности применить метод огибающих. Для таких расстояний оценки $Q(f)$ получены экстраполяцией оценок, полученных для меньших расстояний.

Нужно отметить, что в методе огибающих геометрическое расхождение предполагается в виде $1 / r$, что для изучаемого региона вероятно справедливо лишь до расстояний 50-70 км. Как показывают наблюдения, в районах с континентальной земной корой (к каким относится северо-восточная Бурятия) амплитуды сейсмических колебаний быстро спадают на удалениях от очагов до 50-70 км и медленнее спадают на удалениях 120-150 км и больше [Boore 2003; Atkinson 2004]. На удалениях от 50-70 км до 130-150 км спадания амплитуд вследствие геометрического расхождения практически не наблюдается, что объясняется интенсивными пост-критическими отражениями волн от границы корамантия [Burger et al. 1987, Atkinson 2004]. Если сейсмический очаг расположен в коре, то на удалениях 120-150 км и больше мы наблюдаем волновое поле, которое можно рассматривать как суперпозицию поверхностных волн с геометрическим расхождением $\sim 1 / r^{0.5}$ [Wang and Herrmann 1980; Herrmann and Kijko,1983]. Таким образом, в районах с континентальной корой геометрическое расхождение обычно описывается трехсегментной функцией вида $1 / r$ для $r<r_{1}, 1 / r_{1}$ для $r_{1}<r<r_{2}$ км и $1 / r^{0.5}$ для $r>r_{2}$, где $r_{1}$ $\sim 50-70$ км, $r_{2} \sim 130-150$ км [Boore, 2003].

Так что на удалениях $r>50-70$ км функция $1 / r$ очевидно переоценивает спадание амплитуд вследствие геометрического расхождения, и неупругое поглощение (обратное добротности) при применении метода огибающих оказывается недооцененным, а добротность - переоцененной. Поэтому все полученные оценки $Q(f)$ для расстояний $r>50$ км верифицировались стохастическим моделированием.

По записям ст. «Северомуйск» также оценено изменение длительности сильных движений в зависимости от расстояния до очага. Длительность сильных движений $D_{T}-$ важный параметр стохастического моделирования; она представляет собой сумму длительности, обусловленной эффектами очага $D_{S}$ и длительности, обусловленной эффектами пути распространения $D_{P}$. В стохастическом моделировании используется параметр длительности $D_{95}$, определяемый как интервал сильных движений в секундах между моментами времени, в которые кумулятивный интеграл квадрата ускорения (нормированный к единице в конце записи) достигает 5\% и 95\% от максимума [Вoore, Thompson, 2014]: $D_{95}=D_{S}+D_{P}$. В таблице 1 приведены значения $D_{95}$, рассчитанные для исследуемых записей на горизонтальных компонентах $N S$ и $E W$, а их зависимость от расстояния приведена на рисунке 2. Длительность очагового процесса $D_{S}$ определяется угловой частотой и параметром напряжения, и составляет $\sim 1$ с для исследуемых землетрясений ( $\left.m_{b} \sim 4.2-5.5\right)$, что заметно меньше, чем продолжительность, связанная с эффектами пути $D_{P}$. Пренебрегая $D_{s}$, рассмотрим расчетную продолжительность $D_{95} \sim D_{P}$ (табл. 1).

Длительность $D_{95}$ оценивалась для поперечных волн, т.е. в качестве начальной точки отсчета кумулятивного интеграла квадрата ускорения брался момент вступления $S$ волн, а в качестве последней точки - момент времени, определяемый как окончание 
временного окна регулярных $S$-волн, т.е. момент, в который снижение амплитуд становилось менее заметным - более плавным. Такие достаточно условные оценки моментов начала и окончания окна $S$-волн естественно дали разброс оценок длительности, особенно заметный для записей удаленных землетрясений, где записи обрезаны на кодаволнах (рис. 2). Тем не менее, оценки длительности можно аппроксимировать трехсегментной функцией вида 0 для $0<r<5$ км, $0.222 r$ для $5<r<50$ км и $10+0.015 r$ для $r$ $>50$ км (рис. 2), и эта функция показала согласие с наблюдениями.

По данным о скоростном строении земной коры и верхней мантии (до глубин более 40 км) Байкальской рифтовой зоны и сопредельных районов, полученных методом ГСЗ [Суворов и др., 1999], оценено локальное усиление сейсмических волн в верхних слоях земной коры по отношению к окрестности сейсмических очагов; результаты приведены в таблице 2. Усиление сейсмических волн возникает вследствие снижения сейсмических скоростей и плотностей в земной коре (в частности, как результат процессов выветривания и разрушения земной коры в верхних слоях) при распространении сейсмических волн с глубины к поверхности, в соответствии с законом сохранения плотности потока сейсмической энергии. Локальное усиление $A(f)$ рассчитано по методике, предложенной в работе [Boore, Joyner, 1997]. При оценке локального усиления скорости поперечных волн и средние плотности пород в окрестности очагов выбирались в зависимости от глубин очагов, в соответствии с региональной скоростной моделью [Суворов и др., 1999]. Как видно из таблицы 2, получены невысокие оценки усиления; эти оценки были использованы в качестве входных параметров моделирования записей сейсмостанции «Северомуйск».

\section{РЕЗУЛЬТАТЫ И ОБСУЖДЕНИЕ}

Результаты моделирования приведены на рисунке За-г, где показаны зарегистрированные акселерограммы, NS- и $E W$ - компоненты, и смоделированные максимальные горизонтальные компоненты записей землетрясений в порядке возрастания гипоцентрального расстояния, а также спектры зарегистрированных и рассчитанных акселерограмм.

Программа стохастического моделирования построена таким образом, что рассчитывается серия акселерограмм; по ним находятся средние характеристики колебаний поверхности. На рисунках в качестве рассчитанных показаны единичные акселерограммы из серий рассчитанных акселерограмм и спектры, усредненные в пределах серий рассчитанных акселерограмм. В целом достигнуто достаточно хорошее согласие расчетов и наблюдений. Как видно из рисунка За, на записях близких землетрясений присутствуют высокочастотные шумы ( $f>10-15$ Гц), происхождение которых не вполне понятно.

К сожалению, на сейсмостанциях сети Геофизической Службы РАН не принято изучать в должной степени грунтовые условия, как это делается например на станциях сети сильных движений Японии KiK-net, где определяются состав грунта и сейсмические скорости $P$ - и $S$-волн до глубин $h \sim 100-200$ м. Вместо этого дается краткое описание, например: «Грунт: консолидированный (глыбы, щебень, дресва)». Такие описания позволяют отнести грунт к одному из 4-х классов грунтов, представленных в строительных нормах, но не позволяют использовать имеющиеся записи для оценки отклика грунта. 
Для станции «Северомуйск» нет описания грунтовых условий, поэтому моделирование записей на первом этапе проводилось в предположении скального грунта основания (скала).

Сначала моделировались акселерограммы близких землетрясений, для минимизации числа настраиваемых параметров пути распространения (геометрического расхождения, зависимости длительности сильных движений от расстояния, добротности).

В качестве магнитуд землетрясений в стохастическом моделировании задаются моментные магнитуды $M_{w}$ (на рисунках обозначены $\mathrm{M}$ ); они оценивались как $m_{b}+0.1\left(m_{b}\right.$ взяты в соответствии с данными ISC), т.к. магнитуды $M_{w}$ как правило несколько превышают магнитуды $m_{b}$.

Очаги были представлены как точечные источники; их координаты и глубины выбраны в соответствии с данными ISC. Взята модель излучения $\omega^{-2}$ как наиболее распространенная и удовлетворяющая записям землетрясений.

Параметр напряжения $\Delta \sigma \sim 100$ бар, общий для всех землетрясений, выбран из условия соответствия уровней спектральных амплитуд зарегистрированных и смоделированных записей в диапазоне $1-5$ Гц.

Моделированием спадания спектра акселерограмм на высоких частотах подобраны параметры ослабления волн на высоких частотах каппа $\kappa$ [Anderson, Hough, 1984]; получены оценки $\kappa \sim 0.012$ с, что показывает довольно слабое затухание на высоких частотах, очевидно характерное для данного региона. По волновым формам аксклерограмм подобраны параметры, определяющие форму и длительность волновых форм смоделированных акселерограмм [Boore, 2003].

Предварительно методом огибающих получены оценки добротности $Q(f)$ в виде 60 $f^{1.05}$ для гипоцентральных расстояний $r \sim 15-30$ км, $\sim 80 f^{1.0}$ для $r \sim 40-60$ км, $\sim 90 f^{0.9}$ для $r$ $\sim 100-110$ км. Записи землетрясений с гипоцентральными расстояниями $r \sim 160-220$ км обрезаны по времени, т.е. не включают кода-волны, поэтому нет возможности оценить функцию добротности для таких расстояний. Оценки $Q(f) \sim 150 f^{0.7}$ для $r \sim 160-220$ км получены экстраполяцией и верифицированы в стохастическом моделировании. В целом эти оценки согласуются с оценками добротности соседних территорий, литосферы югозападного фланга Байкальской рифтовой системы, полученными в работе [Добрынина и др., 2011].

Расчеты акселерограмм удаленных землетрясений показали, что кусочнонепрерывная функция геометрического расхождения вида $1 / r$ для гипоцентральных расстояний $r<50$ км, 1/50 для $50 \leq r<150$ км и $1 / r^{0.5}$ для $r>150$ км и кусочно-непрерывная функция увеличения длительности акселерограмм с расстоянием от очага, принимающая значения: 0 для $0<r<5$ км, 0.222 $r$ для $5<r<50$ км и $10+0.015 r$ для $r>50$ км, - в среднем удовлетворяют наблюдениям. Параметры, описывающие длительность акселерограмм, отражают относительно невысокую продолжительность сильных движений местных землетрясений, сравнимую с характеристиками длительности землетрясений Калифорнии или Камчатки.

В целом результаты моделирования акселерограмм в предположении скального основания сейсмостанции «Северомуйск» показывают согласие расчетов и наблюдений во временной области, но формы рассчитанных спектров иногда не вполне соответствует формам спектров зарегистрированных землетрясений (рис. За-г). 
Согласие спектров можно постараться улучшить, если предположить плотный грунт в основании сейсмостанции. Поэтому на втором этапе работы стохастическое моделирование проведено в предположении грунтового основания станции «Северомуйск»; остальные параметры моделирования те же, что и в предположении скального основания. Результаты представлены на рисунке 4а-г.

Параметры грунтовой толщи были выбраны в соответствии с формами спектров зарегистрированных землетрясений: был предположен плотный однородный грунт с $V_{S}$ $\sim 600$ м/с и плотностью $\rho \sim 2.2$ г/см³. Мощность грунтовой толщи оценена в 65 м - по соответствию основных преобладающих частот колебаний $f \sim 1-4$ Гц (рис. 4а-г). Предельные сдвиговые напряжения заданы возрастающими с 2.5 бар у поверхности до 2.8 бар на 65 м. Плотный грунт с близкими параметрами дал хорошее согласие расчетов и наблюдений в г. Петропавловске-Камчатском на «грунтовых» станциях «Институт Вулканологии» (IVS), «Дачная» (DCH), «Аэрологическая» (AER): [Pavlenko, 2013], а также на сейсмостанции «Махачкала» (МАK) в г. Махачкале [Pavlenko, 2020]. Вероятно, такой грунт можно рассматривать как некоторый «типичный» плотный грунт основания. Расчет колебаний на поверхности грунта выполнен по алгоритму нелинейного анализа [Joyner, Chen, 1975]. Рассчитывалось распространение падающих вертикально снизу поперечных сейсмических волн в горизонтально-слоистой толще осадочных пород с вышеописанными характеристиками. Поведение грунта описывалось нормированными зависимостями напряжение-деформация, полученными в лабораторных экспериментах Хардина и Дрневича [Hardin, Drnevich, 1972].

Как видно из рисунка 4, предположение о грунтовом основании станции позволило в некоторых случаях улучшить согласие расчетов и наблюдений в спектральной области, однако в целом по результатам моделирования вообще говоря трудно сделать выбор в пользу скального или грунтового основания.

При этом для одних землетрясений можно отметить некоторую недооценку интенсивности и пиковых ускорений (как для скального, так и для грунтового основания), а для других - переоценку. На рисунке 1 области очагов этих землетрясений отмечены красными и синими кругами, соответственно. Наиболее вероятной причиной этого представляется различное поглощение $Q(f)$ для тех и других очагов: для землетрясений, отмеченных красными кругами (1-я группа), в нашем моделировании поглощение завышено (предполагается более высоким чем есть на самом деле), а для землетрясений, отмеченных синими кругами (2-я группа), занижено. Как видно из рисунков Зв и 4в, для группы землетрясений с близкими очагами: 8.02.2006, 3.08.2006, 4.07.2007, 27.08.2007 (рис. 1) дополнительное поглощение наблюдается на частотах 10-20 Гц.

Различия в поглощении очевидно связаны с геологической структурой региона (рис. 1): очаги землетрясений 2-й группы располагаются под горными хребтами, и поглощение сейсмических волн на путях их распространения к сейсмостанции выше, чем принято в моделировании (выше оцененного среднего по региону).

Таким образом, получены характеристики излучения и распространения сейсмических волн в северо-восточной Бурятии, которые могут быть использованы для прогноза параметров сильных движений в этом регионе; они приведены в таблице 3. В будущем, с накоплением записей сильных землетрясений в регионе, эти оценки должны быть уточнены. 
Полученные оценки сброшенного напряжения $\Delta \sigma \sim 100$ бар сходны с оценками этого параметра для восточных США [Boore, Atkinson, 1987] и Камчатки [Павленко, 2011; Pavlenko, 2013]. Оценки добротности коры и верхней мантии невысоки и близки к аналогичным оценкам, полученным для Байкальской рифтовой зоны другими авторами [Добрынина и др., 2011], для северного Кавказа [Павленко, 2016; Павленко и Павленко, 2016] и центральной Японии [Aki, Chouet, 1975].

В своей совокупности, полученные параметры распространения сейсмических волн: функция добротности, геометрическое расхождение, каппа, длительность сильных движений, - близки к аналогичным параметрам коровых землетрясений северного Кавказа и центральной Японии, но параметры сброшенного в очагах напряжения выше, и следовательно, интенсивность и пиковые ускорения (при фиксированных магнитуде и расстоянии) также будут выше в Бурятии, чем на северном Кавказе.

Изучаемый район северо-восточной Бурятии характеризуется достаточно большой плотностью сейсмогенных структур - линеаментов, и типичное сценарное землетрясение (создающее нагрузки, на которые рассчитываются сейсмостойкие конструкции) имеет моментную магнитуду $M_{w} \sim 7.0$ и эпицентральное расстояние 25 км. На рисунке 5 представлена акселерограмма (максимальная горизонтальная компонента) такого сценарного землетрясения и ее амплитудный спектр, рассчитанные на грунтах, описанных выше как грунтовое основание станции «Северомуйск». Пиковые ускорения при таком землетрясении оцениваются в 204-236 cм/ ${ }^{2}$, скорости - 17-20 cм/с, а преобладающие периоды колебаний - 0,57 с для ускорений и 3,41 с для скоростей.

Автор благодарит Геофизическую Службу РАН за записи землетрясений сейсмостанции «Северомуйск».

\section{ЛИТЕРАТУРА}

Гусев А.А. Свойства и природа короткопериодного излучения очага землетрясения // Диссертация в форме научного доклада на соискание ученой степени доктора физико-математических наук, Москва, 1993.

Добрынина А.А., Чечельницкий В.В., Саньков В.А. Сейсмическая добротность литосферы юго-западного фланга Байкальской рифтовой системы // Геология и геофизика, 2011, т. 52 (5), с. 712-724.

Еманов А.Ф., Еманов А.А., Павленко О.В., Фатеев А.В., Куприш О.В., Подкорытова В.Г. Колыванское землетрясение 09.01.2019 г. с $\mathrm{M}_{\mathrm{L}}=4.3$ и особенности наведенной сейсмичности в условиях Горловского угольного бассейна // Вопросы инженерной сейсмологии, 2019, т. 46 (4), с. 29-45.

Павленко О.В. Характеристики поглощения сейсмических волн в коре и верхней мантии северо-западной части Кавказа // Физика Земли, 2008, № 6, с. 52-60.

Павленко О.В. Изучение региональных характеристик излучения и распространения сейсмических волн на северном Кавказе посредством моделирования акселерограмм // Физика Земли, 2009, № 10, с. 38-48.

Павленко О. В. Различия региональных характеристик излучения и распространения сейсмических волн на Камчатке и северном Кавказе // Доклады Академии наук, 2011, т. 438 (5), с. 687-693.

Павленко В. А., Павленко О. В. Поглощение сейсмических волн в коре и верхней мантии в окрестностях сейсмостанции “Кисловодск” // Физика Земли, 2016, № 4, с. 24-34. 
Павленко О.В. Характеристики излучения и распространения сейсмических волн на Северном Кавказе, оцененные по записям сейсмостанций «Сочи» и «Анапа» // Вопросы инженерной сейсмологии, 2016, 43 (1), с. 49-61.

Павленко О.В., Тубанов Ц.А. Характеристики излучения и распространения сейсмических волн в Байкальской рифтовой зоне, оцененные моделированием акселерограмм зарегистрированных землетрясений // Физика Земли, 2017, т. 53 (1), с. 1831.

Суворов В.Д., Мишенькина 3.Р., Петрик Г.В., Шелудько И.Ф. Земная кора и ее изостатическое состояние в Байкальской рифтовой зоне и прилегающих территориях по данным ДСС // Геология и геофизика, 1999, № 40, с. 303-316.

Abubakirov I.R., Gusev A.A. Estimation of scattering properties of lithosphere of Kamchatka based on Monte-Carlo simulation of record envelope of a near earthquake // Phys. Earth Planet. Inter., 1990, v. 64, p. 52-67.

Aki K., Chouet B. Origin of the coda waves: source, attenuation and scattering effects // J. Geophys. Res., 1975, n. 80, p. 3322-3342.

Aki K., Irikura K. Characterization and mapping of earthquake shaking for seismic zonation // Proc $4^{\text {th }}$ Int. Conf. on Seismic Zonation, 1991, Aug. 25-29, Stanford, California, v. 1, p. 61-110.

Anderson J.G., Hough S.E. A model for the shape of the Fourier amplitude spectrum of acceleration at high frequencies // Bull. Seism. Soc. Am., 1984, v. 74, p. 1969-1993.

Atkinson G.M. Empirical attenuation of ground-motion spectral amplitudes in southeastern Canada and the northeastern United States // Bull. Seism. Soc. Am., 2004, v. 94, p. 1979-1995.

Boore D.M., Atkinson G.M. Stochastic Prediction of Ground Motion and Spectral Response Parameters at Hard-rock Sites in Eastern North America // Bull. Seism. Soc. Am., 1987, v. 77, p. 440-467.

Boore D.M., Joyner W.B. Site amplifications for generic rock sites // Bull. Seism. Soc. Am., 1997, v. 87, p. 327-341.

Boore D.M. Simulation of Ground Motion Using the Stochastic Method // Pure Appl. Geoph., 2003, v. 160, p. 635-676.

Boore D.M., Thompson E.M. Path durations for use in the stochastic-method simulation of ground motions // Bull. Seism. Soc. Am., 2014, v. 104(5), p. 2541-2552.

Burger R.W., Sommerville P.G., Barker J.S., Herrmann R.B., Helmberger D.V. The effect of crustal structure on strong ground motion attenuation relations in eastern North America // Bull. Seism. Soc. Am., 1987, v. 77, p. 420-439.

Joyner W.B., Chen T.F. Calculation of nonlinear ground response in earthquakes // Bull. Seism. Soc. Am., 1975, v. 65 (5), p. 1315-1336.

Halldorsson B., Papageorgiou A.S. Calibration of the Specific Barrier Model to Earthquakes of Different Tectonic Regions // Bull. Seism. Soc. Am., 2005, v. 95 (4), p. 12761300.

Hanks T.C., McGuire R.K. The character of high frequency strong ground motion // Bull. Seism. Soc. Am., 1981, v. 71, p. 2071-2095.

Hardin B.O., Drnevich V.P. Shear modulus and damping in soils: Design equations and curves // Proc. Am. Soc. Civil Eng., J. Soil Mech. Found. Div., 1972, v. 98, p. 667-692.

Herrmann R.B., Kijko A. Modeling some empirical vertical component Lg relations // Bull. Seism. Soc. Am., 1983, v. 73, p. 157-171. 
Pavlenko O.V. Simulation of Ground Motion from Strong Earthquakes of Kamchatka Region (1992-1993) at Rock and Soil Sites // Pure Appl. Geoph., 2013, v. 170 (4), p. 571-595.

Pavlenko O., Kozlovskaya E. Characteristics of radiation and propagation of seismic waves in the Northern Finland estimated based on records of local earthquakes // Pure Appl. Geoph., 2018, v. 175 (12), p. 4197-4223, https://doi.org/10.1007/s00024-018-1919-5.

Pavlenko O.V. Regional Characteristics of Radiation and Propagation of Seismic Waves in the North-Eastern Caucasus // Russ. J. Earth Sci., 2020, v. 20 (3).

Wang C.Y., Herrmann B.B. A numerical study of P-, SV-, and SH-wave generation in a plane layered medium // Bull. Seism. Soc. Am., 1980, v. 70, p. 1015-1036. 


\section{Подписи к рисункам:}

Рис. 1. Карты эпицентров землетрясений, зарегистрированных сейсмостанцией «Северомуйск» SVKR, изучаемых в настоящей работе. Треугольником показано расположение сейсмостанции.

Рис. 2. Оценки длительности сильных движений $D_{95}$ в зависимости от гипоцентрального расстояния.

Рис. 3. Зарегистрированные (вверху и внизу) и рассчитанные (в середине) акселерограммы землетрясений, зарегистрированных станцией SVKR и амплитудные спектры Фурье ускорений: $N S$ - и $E W$ - компонент зарегистрированных акселерограмм (красные и черные линии) и модельных акселерограмм (синие толстые линии). По вертикальным осям - см/с², по горизонтальным осям - с. Расчеты в предположении скального основания сейсмостанции.

Рис. 4. Зарегистрированные (вверху и внизу) и рассчитанные (в середине) акселерограммы землетрясений, зарегистрированных станцией SVKR и амплитудные спектры Фурье ускорений: $N S$ - и $E W$ - компонент зарегистрированных акселерограмм (красные и черные линии) и модельных акселерограмм (синие толстые линии). По вертикальным осям - см/ ${ }^{2}$, по горизонтальным осям - с. Расчеты в предположении грунтового основания сейсмостанции.

Рис. 5. Акселерограмма (максимальная горизонтальная компонента) сценарного землетрясения (магнитуда $M_{w} \sim 7.0$, эпицентральное расстояние $\sim 25$ км, глубина очага 12 км) для северо-восточной Бурятии и ее амплитудный спектр. 
Таблица 1. Информация о землетрясениях, зарегистрированных в 2005-2010 годах станцией «Северомуйск» SVKR (координаты $56.159^{\circ}$ с.ш., $113.52^{\circ}$ в.д.)

\begin{tabular}{|c|c|c|c|c|c|c|c|c|c|}
\hline & Дата & Время & $\begin{array}{c}\text { Широт } \\
\text { a } \\
\end{array}$ & Долгота & $h, \mathrm{KM}$ & $r, \mathrm{KM}$ & $m_{b}$ & PGA & $\mathrm{D}_{95}$ \\
\hline 1 & 21.8.2005 & 22:31:28.9 & 55.2278 & 112.915 & 17.2 & 108 & $4.2(4.5)$ & 1.10 .9 & 1314 \\
\hline 2 & 8.02.2006 & $15: 31: 18.4$ & 55.3599 & 110.796 & 2.7 & 191 & $4.7(4.8)$ & 1.00 .8 & 1513 \\
\hline 3 & 3.08.2006 & 11:56:43.2 & 55.3464 & 110.439 & 10.0 & 212 & $4.5(4.7)$ & 0.40 .4 & 1414 \\
\hline 4 & 3.08.2006 & $16: 57: 15.0$ & 55.3671 & 110.441 & 10.8 & 211 & $4.5(4.8)$ & 0.60 .3 & 1315 \\
\hline 5 & 4.12.2006 & 9:14:4.6 & 55.7559 & 110.089 & 12.0 & 219 & $5.2(5.3)$ & 49.131 .5 & 1113 \\
\hline 6 & 11.12.2006 & 9:8:46.3 & 55.7881 & 110.164 & 11.3 & 213 & $4.9(5.0)$ & 1.71 .8 & 1413 \\
\hline 7 & 15.12.2006 & 22:35:27.8 & 55.6373 & 110.253 & 13.3 & 212 & $4.3(4.7)$ & 1.10 .7 & 1212 \\
\hline 8 & 21.01.2007 & $10: 44: 34.4$ & 55.0098 & 111.654 & 1.5 & 170 & $4.3(4.6)$ & 0.80 .7 & 1314 \\
\hline 9 & 21.03.2007 & 14:55:43.1 & 55.7692 & 113.529 & 7.0 & 42 & $4.4(4.4)$ & 3.86 .1 & 1011 \\
\hline 10 & 5.04 .2007 & 13:22:53.7 & 56.0772 & 114.453 & 14.4 & 59 & $5.0(5.2)$ & 14.912 .3 & 76 \\
\hline 11 & 4.07.2007 & 01:23:23.9 & 55.5091 & 110.392 & 10.8 & 208 & $5.3(5.5)$ & 1.71 .2 & 1514 \\
\hline 12 & 23.08.2007 & 04:49:19.4 & 55.9657 & 113.492 & 21.8 & 30 & $4.9(5.1)$ & 23.728 .2 & 33 \\
\hline 13 & 27.08.2007 & 10:09:30.5 & 55.4729 & 110.402 & 1.7 & 208 & $4.8(4.9)$ & 0.90 .7 & 1110 \\
\hline 14 & 3.01 .2009 & 03:50:15.6 & 56.2059 & 113.429 & 4.5 & 16 & $4.5(4.6)$ & 81.3143 & 44 \\
\hline 15 & 10.06.2009 & 18:51:59.1 & 55.4745 & 111.185 & 17.3 & 164 & $4.9(5.0)$ & 1.71 .8 & 1011 \\
\hline 16 & 8.12 .2010 & 10:42:07.5 & 56.2033 & 113.130 & 10.0 & 27 & $4.2(4.6)$ & 15.628 .7 & 55 \\
\hline
\end{tabular}


Таблица 2. Параметры локального усиления принятые в расчетах

\begin{tabular}{|c|c|}
\hline$f, \mathrm{~Hz}$ & $A(f)$ \\
\hline 0.021 & 1.25 \\
\hline 0.024 & 1.289 \\
\hline 0.046 & 1.358 \\
\hline 0.057 & 1.378 \\
\hline 0.194 & 1.438 \\
\hline 0.343 & 1.462 \\
\hline 1.283 & 1.557 \\
\hline
\end{tabular}


Таблица 3. Параметры, использованные для моделирования акселерограмм землетрясений, зарегистрированных сейсмостанцией «Северомуйск»

\begin{tabular}{|c|c|}
\hline Параметр напряжения $\Delta \sigma$ & 100 бар \\
\hline Геометрическое расхождение & $\begin{array}{c}1 / r \text { для } r<50 \mathrm{Kм} \\
1 / 50 \text { для } 50 \leq r<150 \mathrm{Kм} \\
1 / r^{0.5} \text { для } r>150 \text { км }\end{array}$ \\
\hline$Q(f)$ & $\begin{array}{c}\sim 60 f^{1.05} \text { для } r \sim 15-30 \mathrm{kм}, \\
\sim 80 f^{1.0} \text { для } r \sim 40-60 \mathrm{kм,} \\
\sim 90 f^{0.9} \text { для } r \sim 100-110 \mathrm{kм} \text {, } \\
\sim 150 f^{0.7} \text { для } r \sim 160-220 \mathrm{kм}\end{array}$ \\
\hline $\begin{array}{l}\text { Параметр длительности сигнала } \\
d u r(r)\end{array}$ & $\begin{array}{c}0 \text { для } 0<r<5 \text { км } \\
0.222 r \text { для } 5<r<50 \text { км } \\
10+0.015 r \text { для } r>50 \text { км }\end{array}$ \\
\hline Каппа $\kappa$ & 0.012 c \\
\hline $\begin{array}{l}\text { Скорость } S \text {-волн в земной коре на } \\
\text { глубинах очагов (в среднем) }\end{array}$ & $3.8 \mathrm{KM} / \mathrm{c}$ \\
\hline $\begin{array}{l}\text { Средняя плотность земной коры на } \\
\text { глубинах очагов (в среднем) }\end{array}$ & $2.6 \Gamma / \mathrm{cm}^{3}$ \\
\hline
\end{tabular}




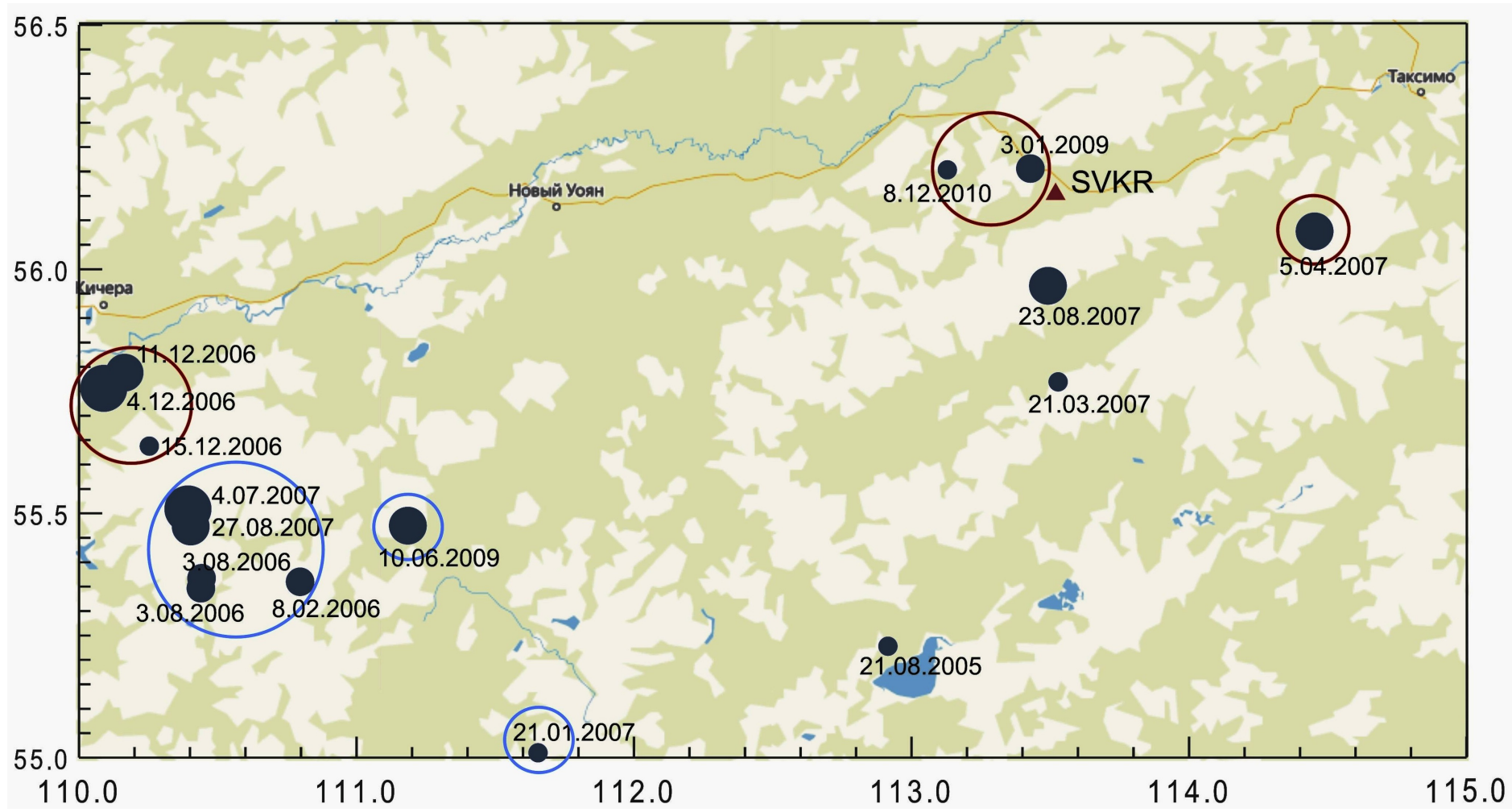




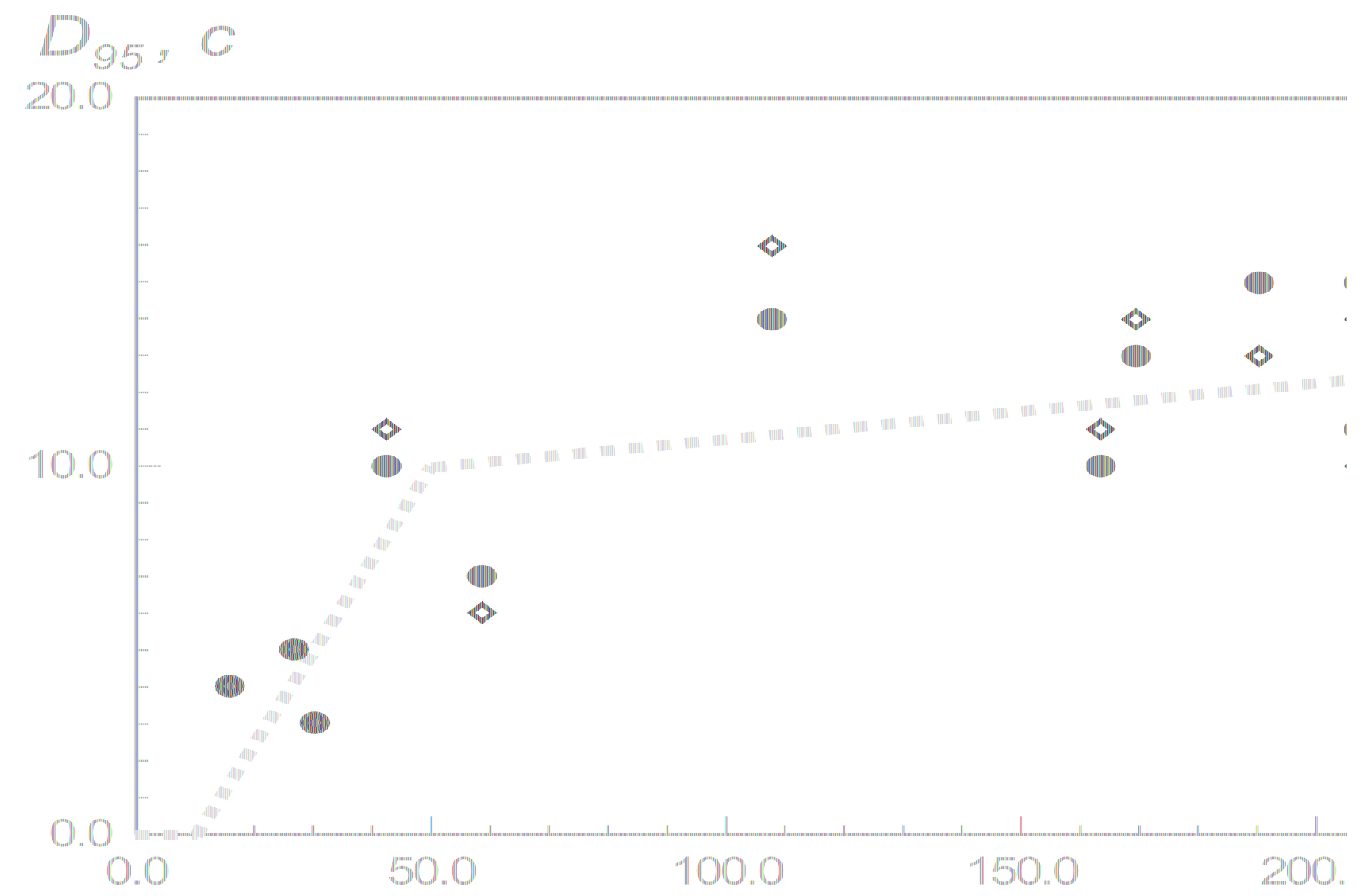


3.01.2009 $\mathrm{M} \sim 4.5$ (4.6), $r \sim 15.6$ км
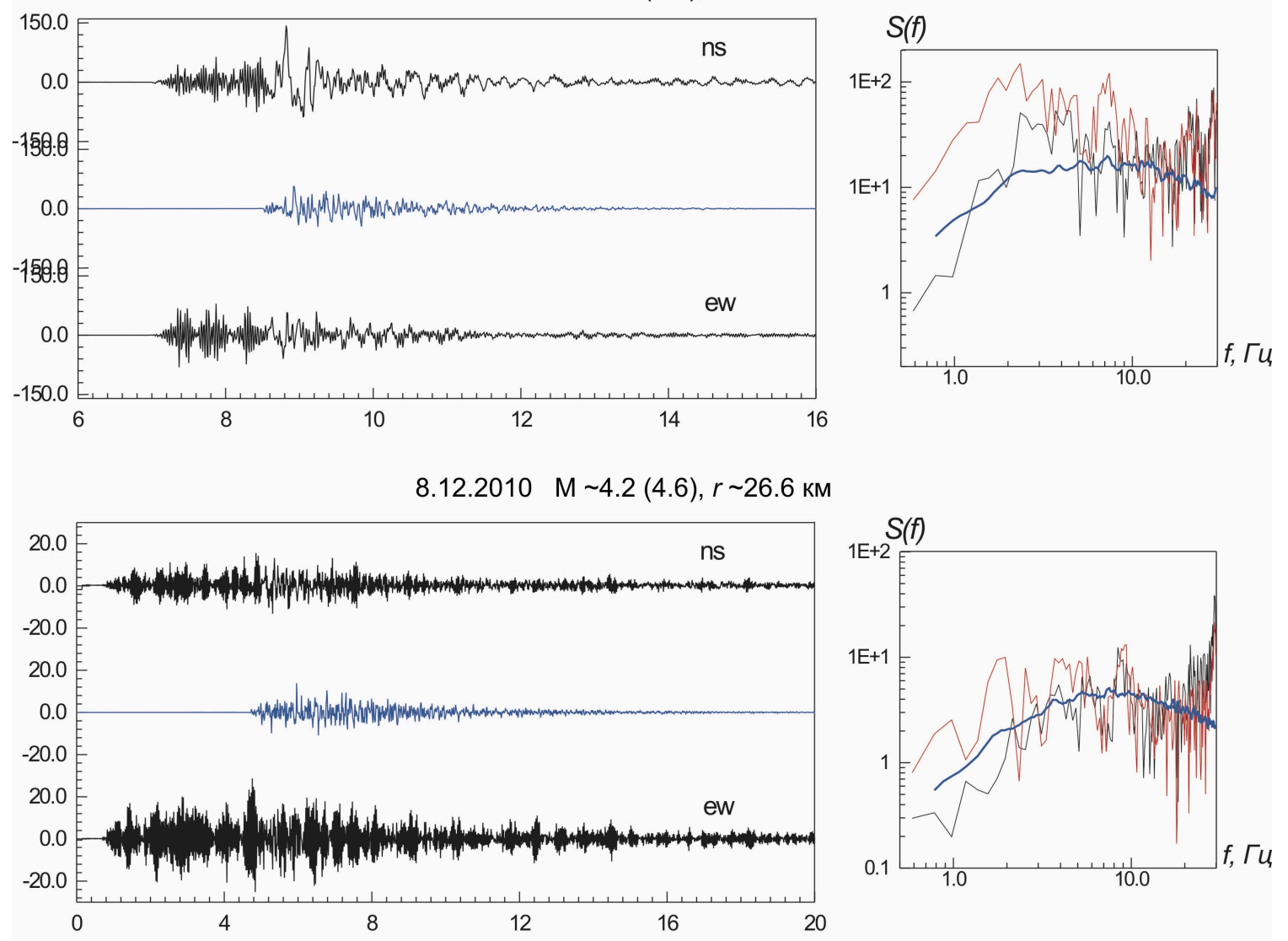

23.08.2007 M 4.9 (5.1), $r \sim 30.1 \mathrm{KM}$
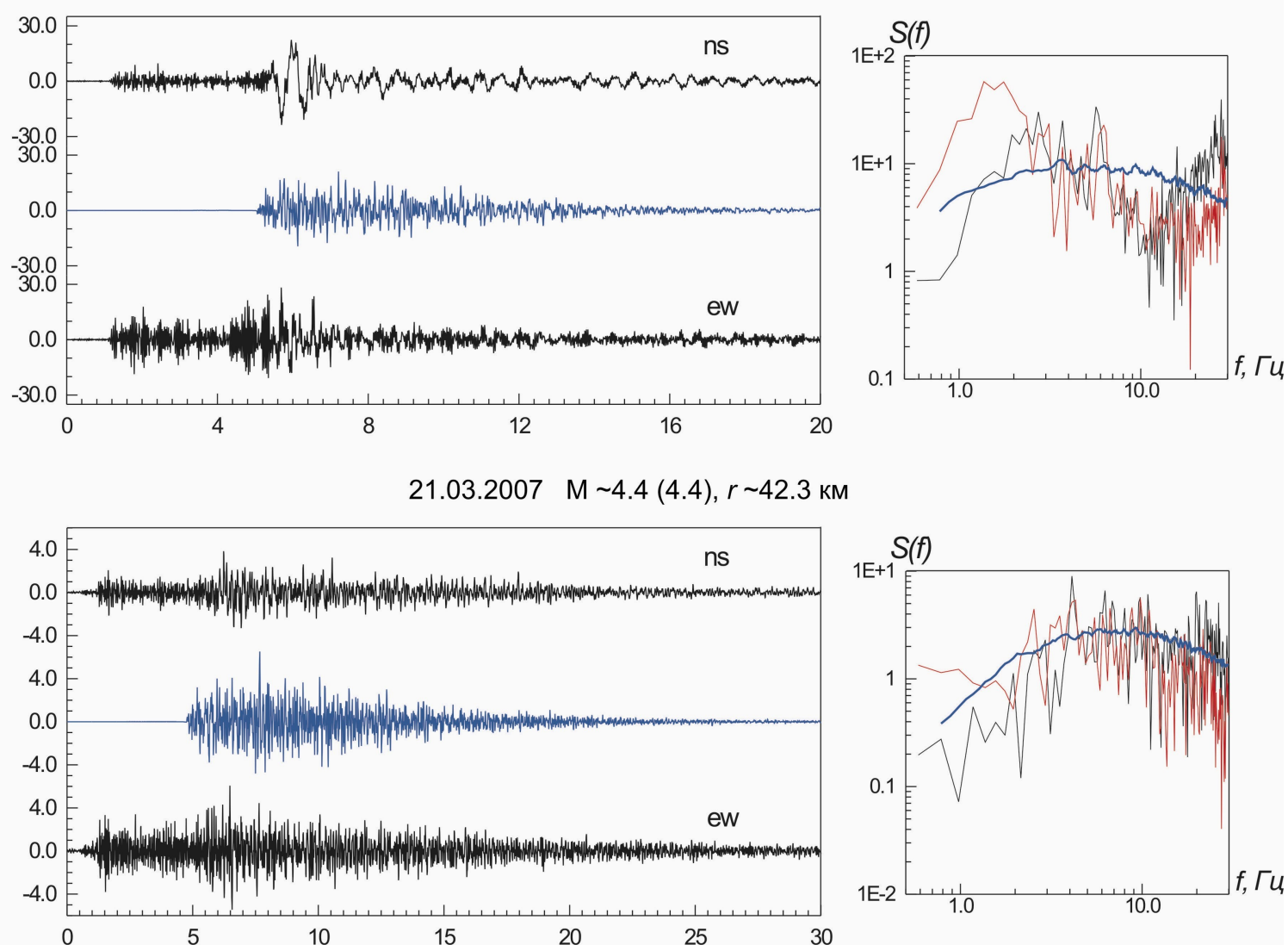
$5.04 .2007 \mathrm{M} \sim 5.0(5.2), r \sim 58.6$ км
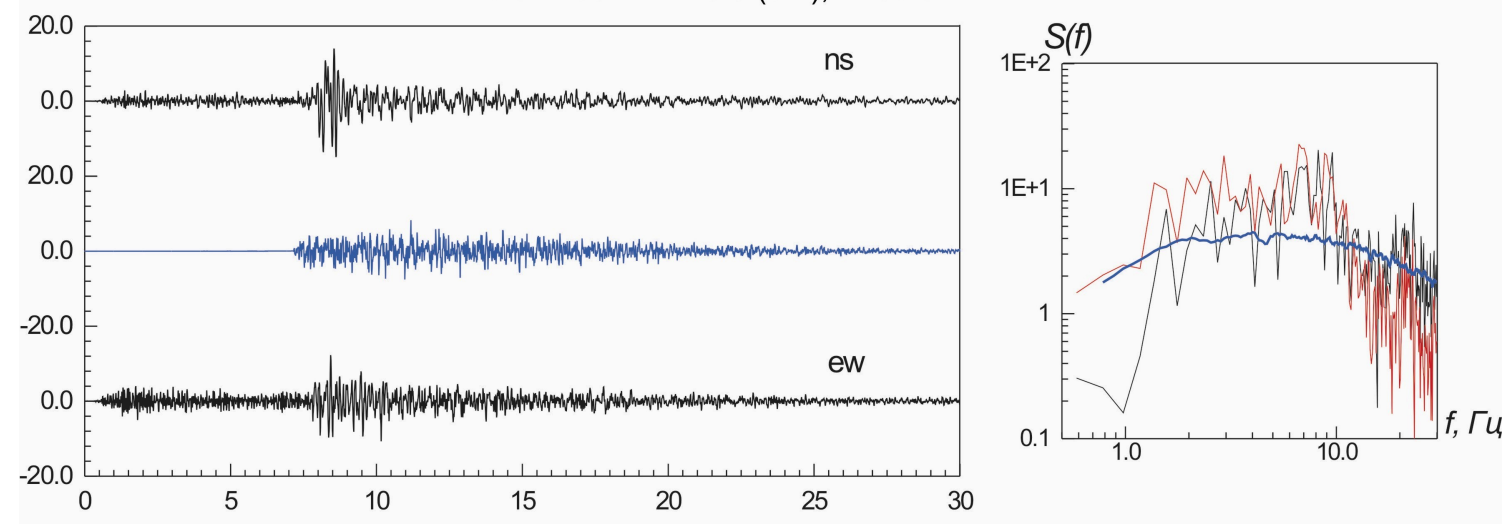

21.08.2005 $\mathrm{M} \sim 4.2(4.5), r \sim 108 \mathrm{kM}$
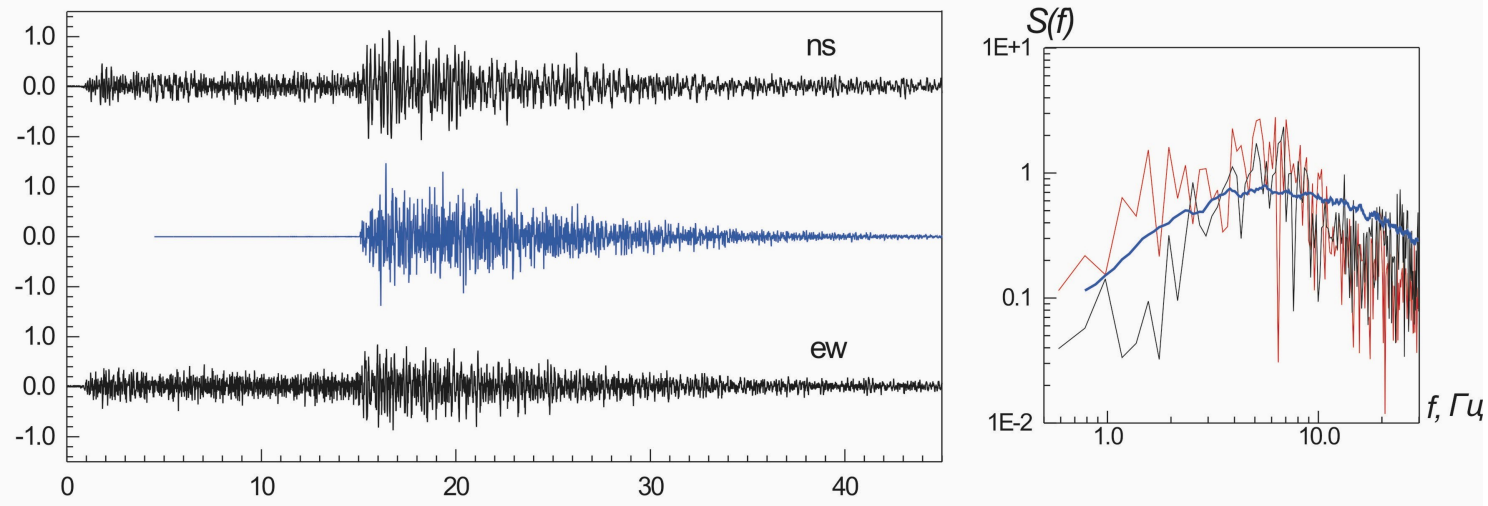

10.06.2009 $\mathrm{M} \sim 4.9(5.0), r \sim 164 \mathrm{kM}$
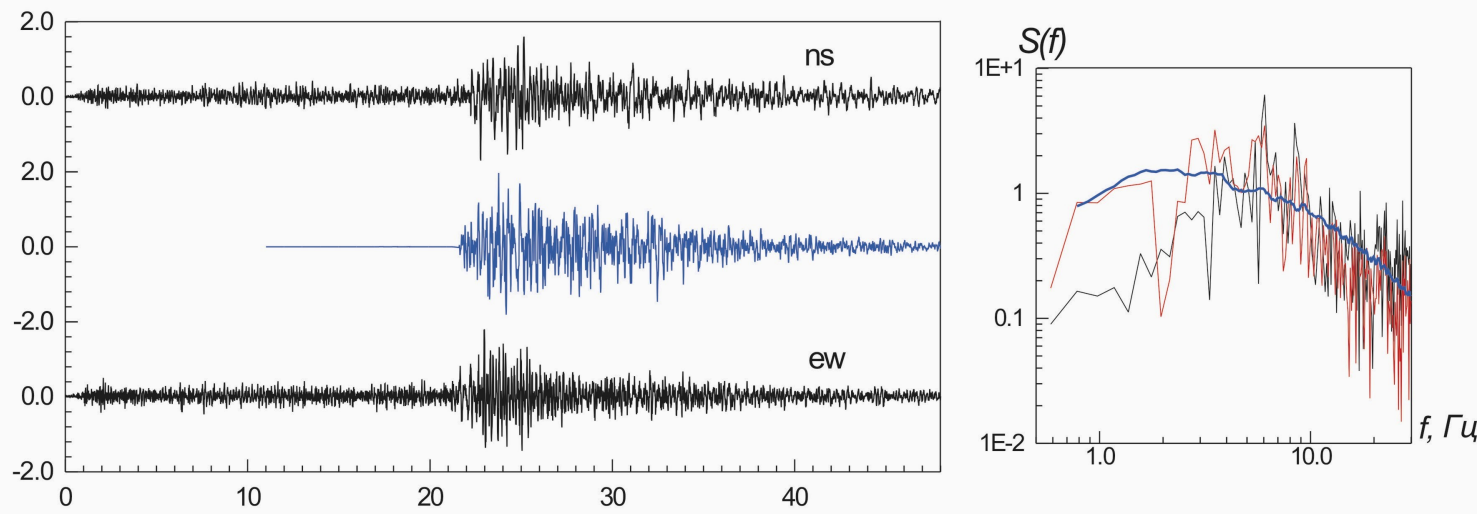

21.01.2007 $\mathrm{M} \sim 4.3(4.6), r \sim 170 \mathrm{kM}$
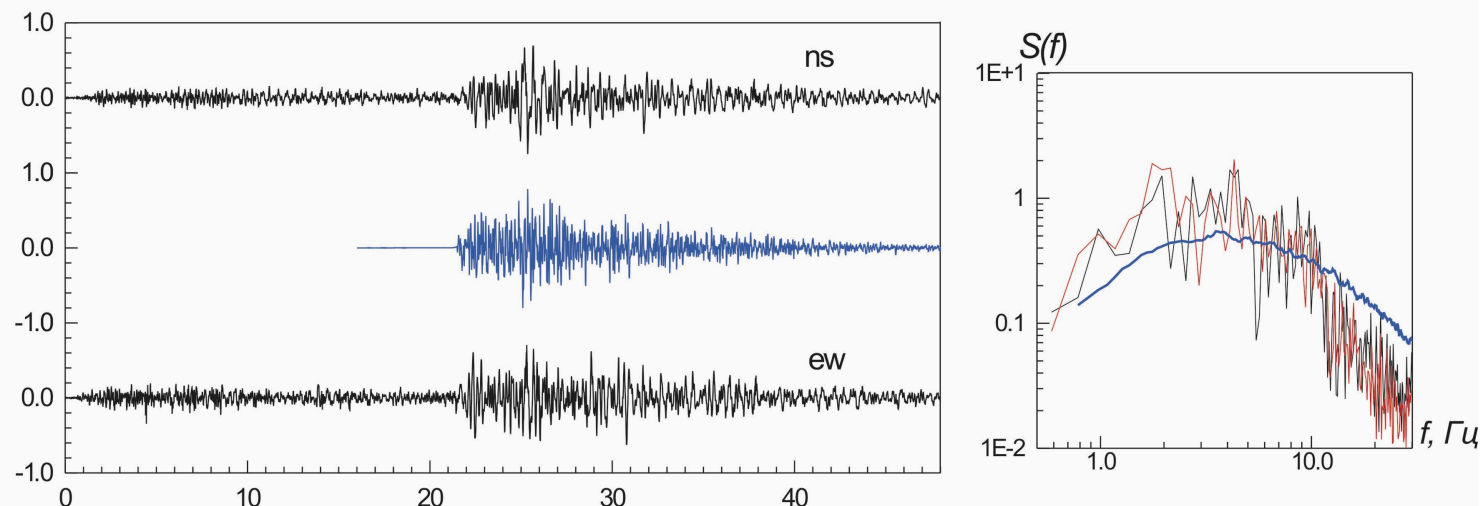
8.02.2006 $\mathrm{M} \sim 4.7(4.8), r \sim 191 \mathrm{\kappa м}$
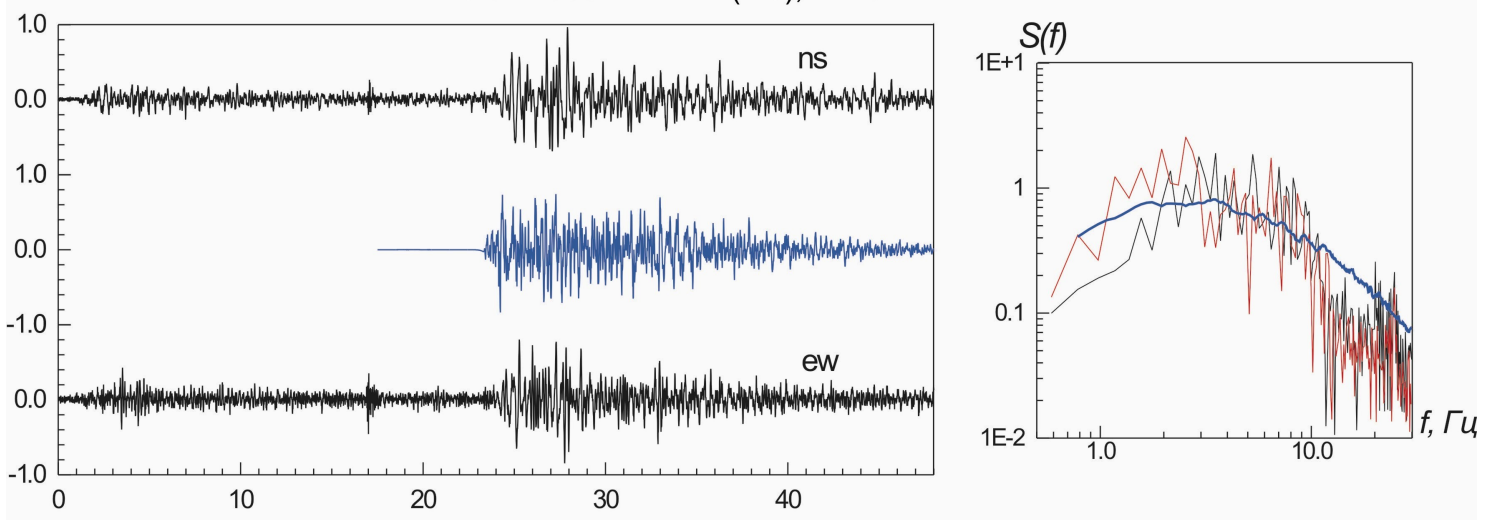

4.07.2007 M 5.3 (5.5), $r \sim 208$ км
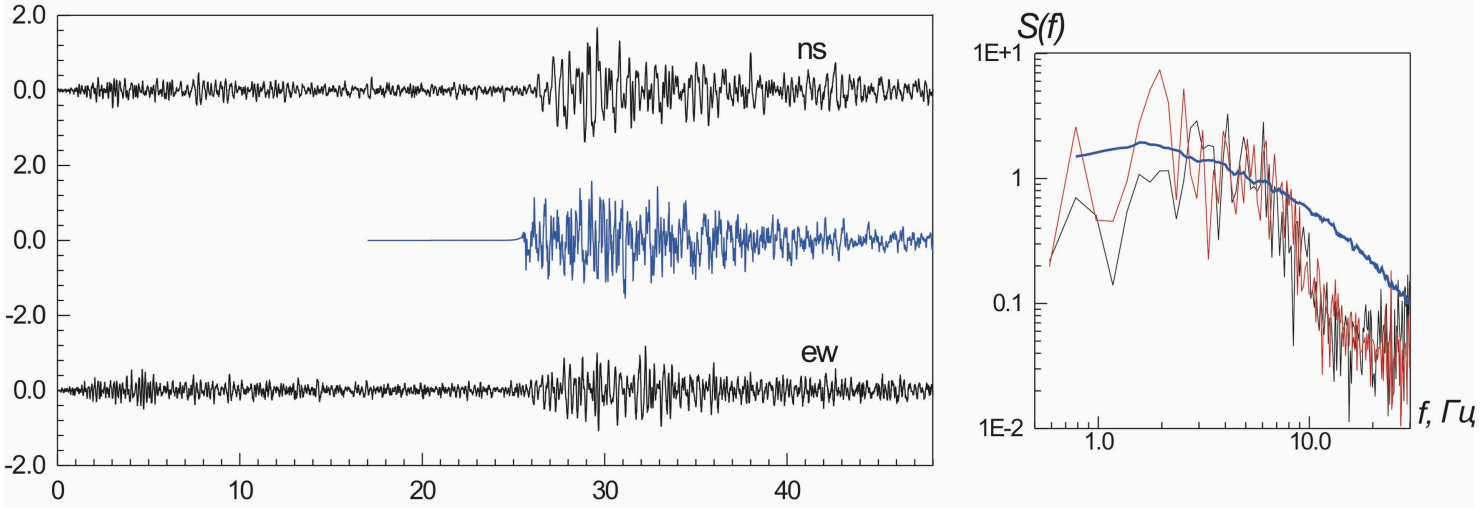

27.08.2007 $\mathrm{M} \sim 4.8$ (4.9), $r \sim 208$ км
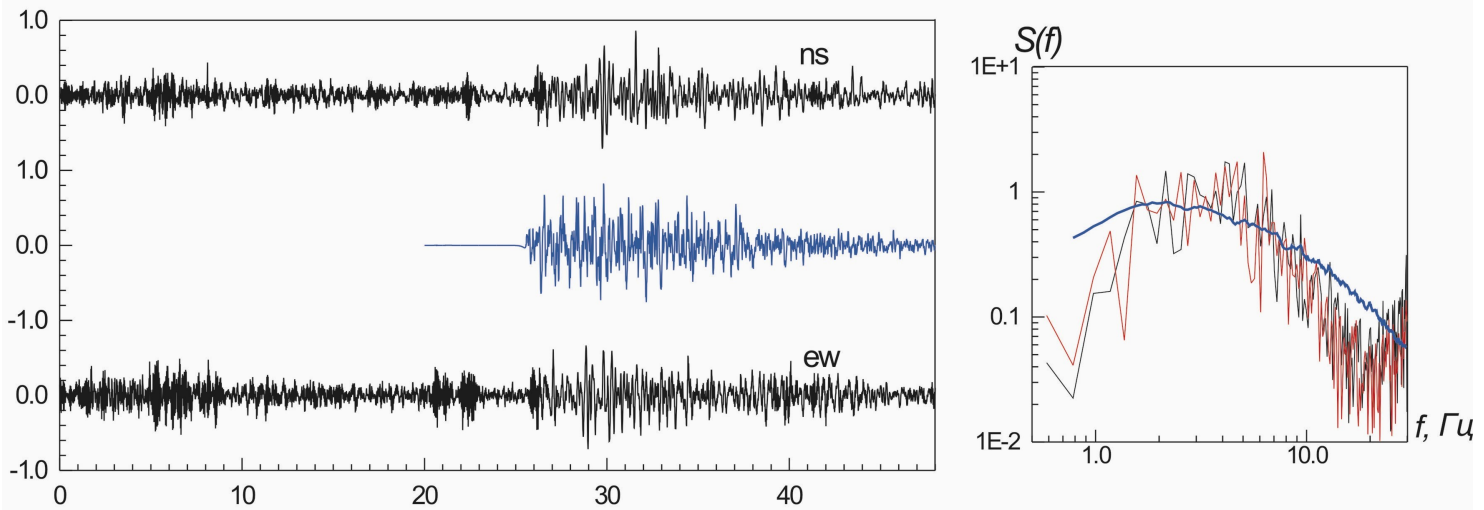

3.08.2006 $\mathrm{M} \sim 4.5(4.8), r \sim 211 \mathrm{KM}$
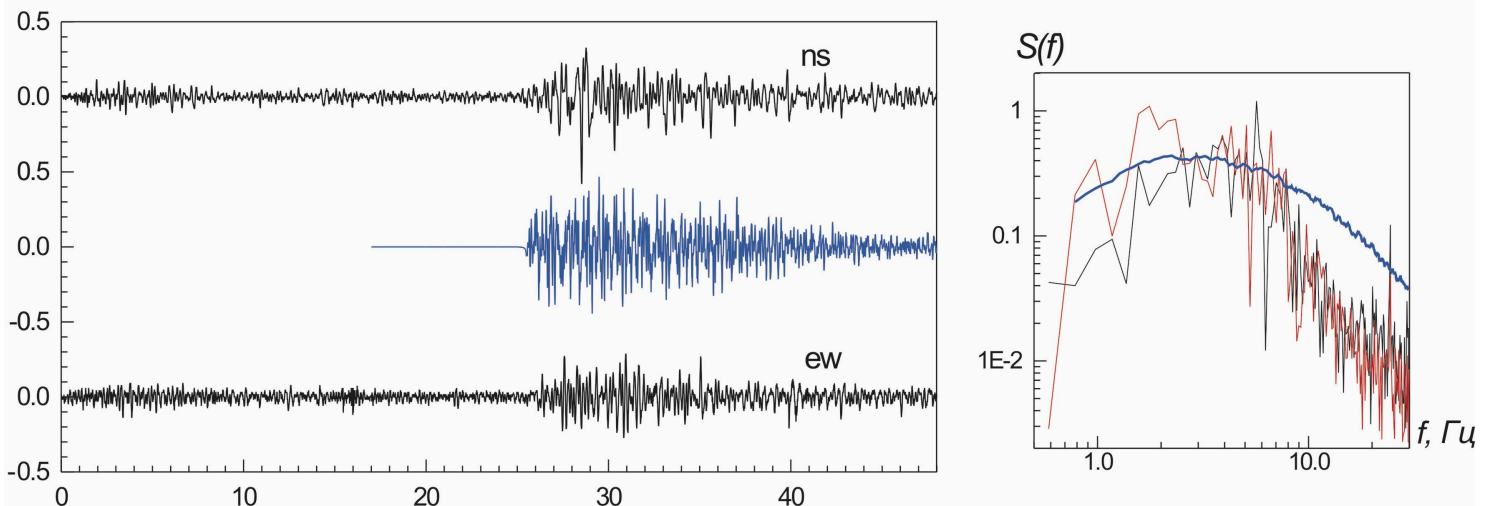
$3.08 .2006 \mathrm{M} \sim 4.5(4.7), r \sim 212 \mathrm{kM}$
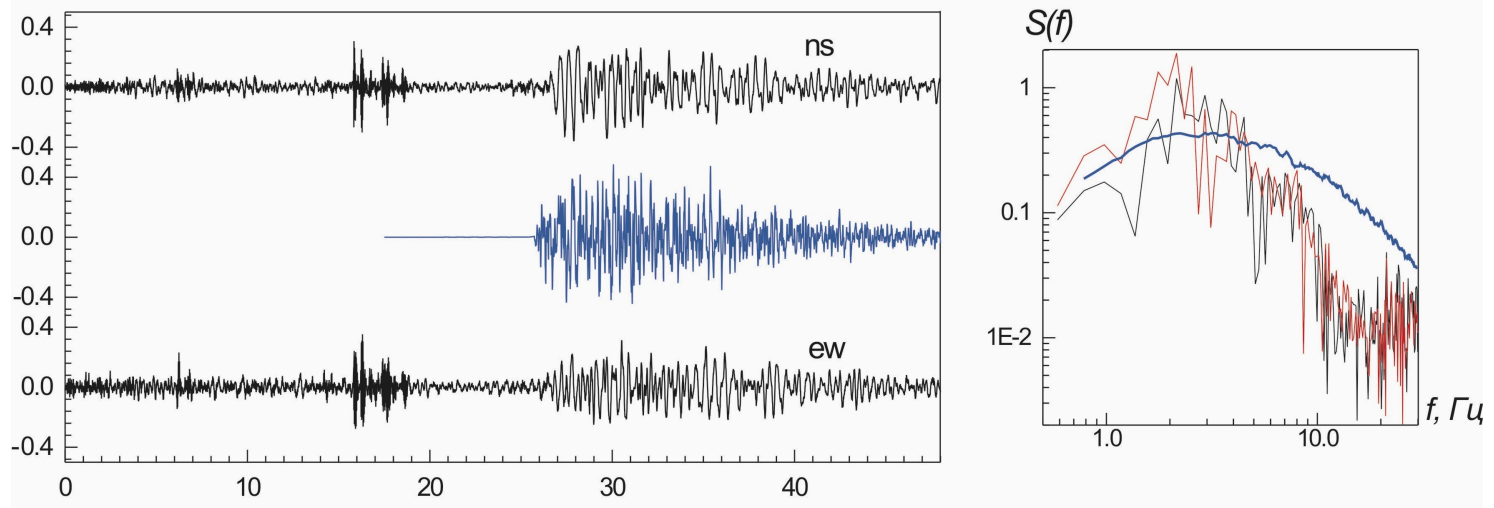

15.12.2006 $\mathrm{M} \sim 4.3(4.7), r \sim 212 \mathrm{kM}$
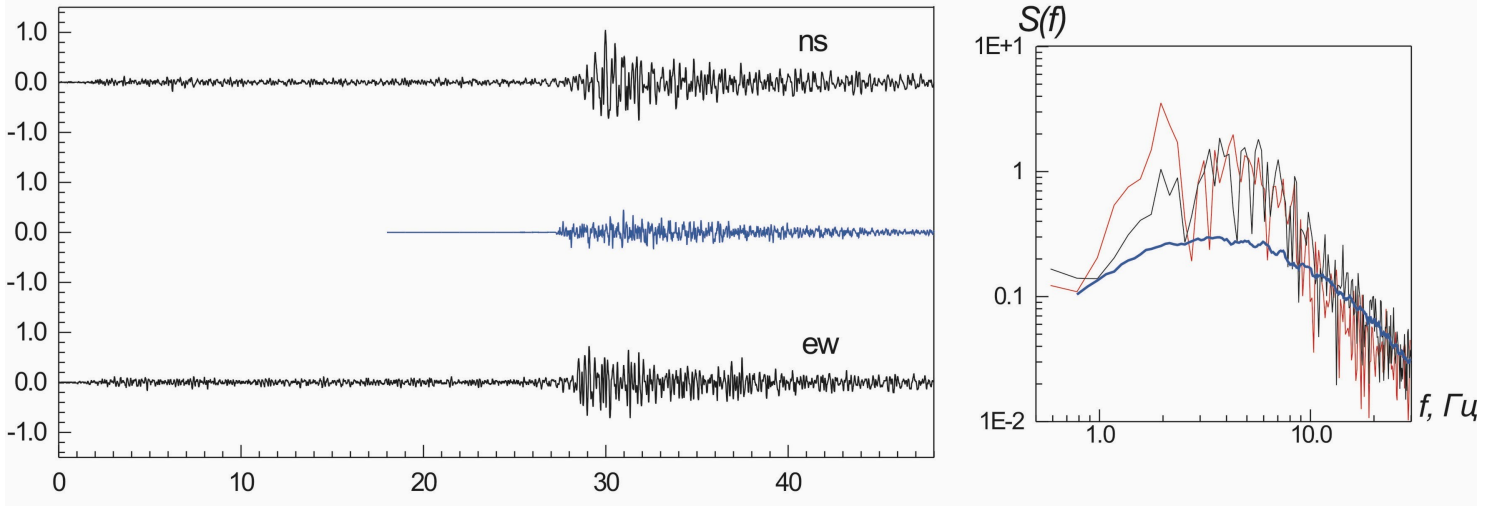

11.12.2006 M 4.9 (5.0), $r \sim 213 \mathrm{kM}$
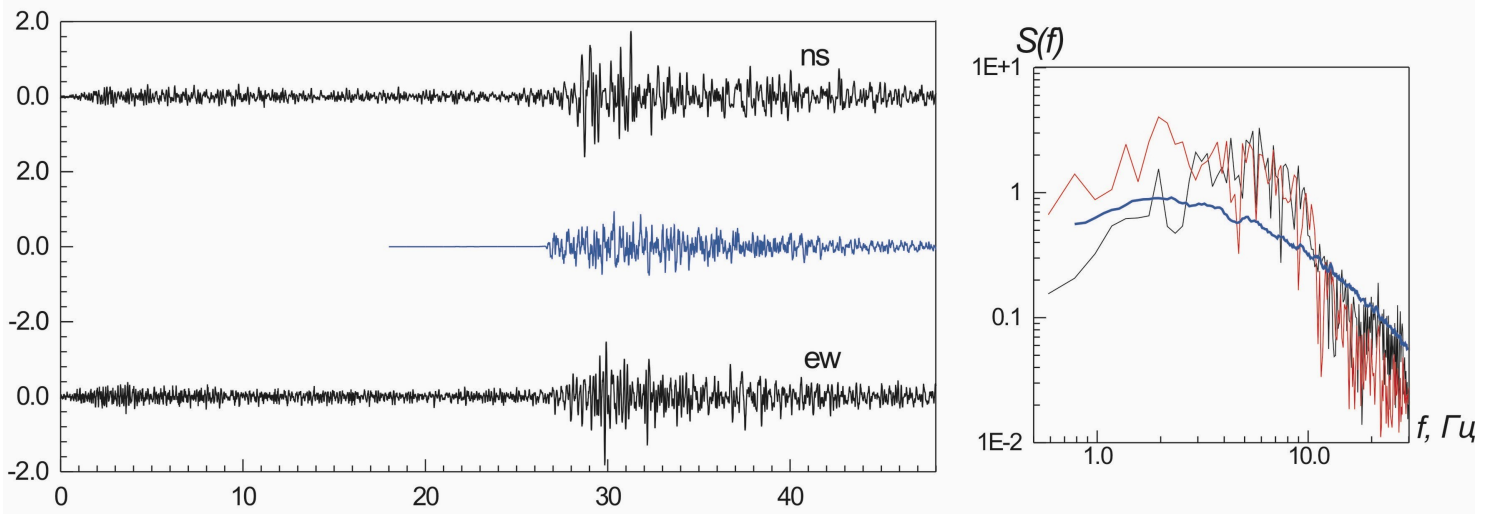

4.12.2006 M 5.2 (5.3), $r \sim 219$ км
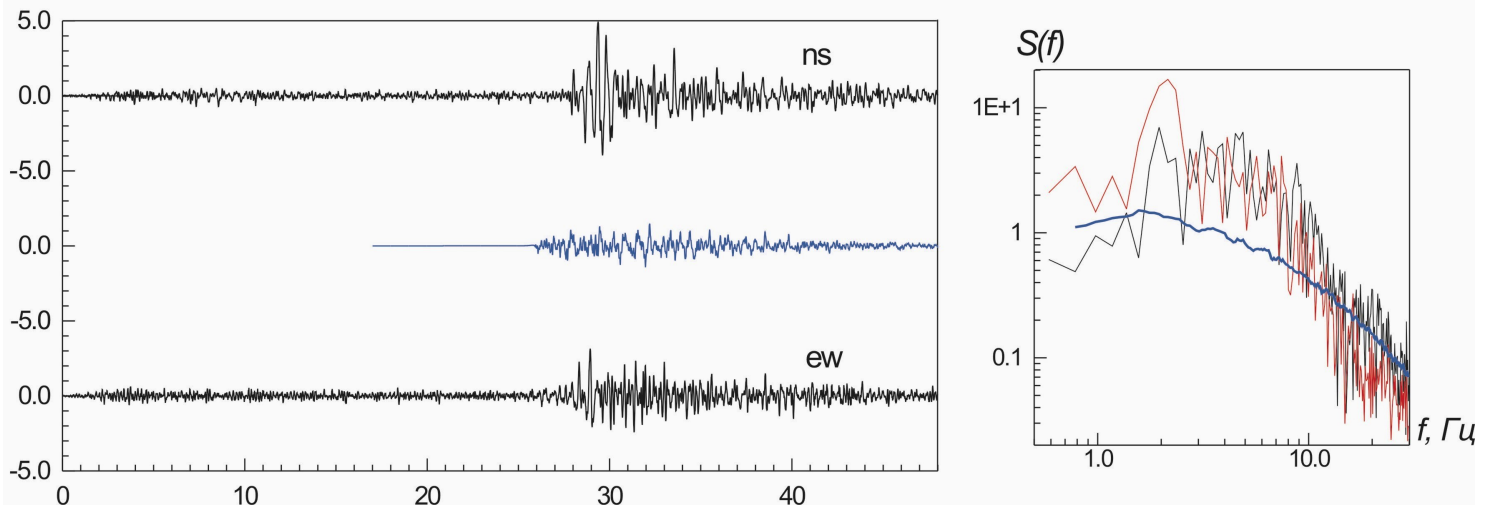
3.01.2009 $\mathrm{M} \sim 4.5$ (4.6), $r \sim 15.6$ км
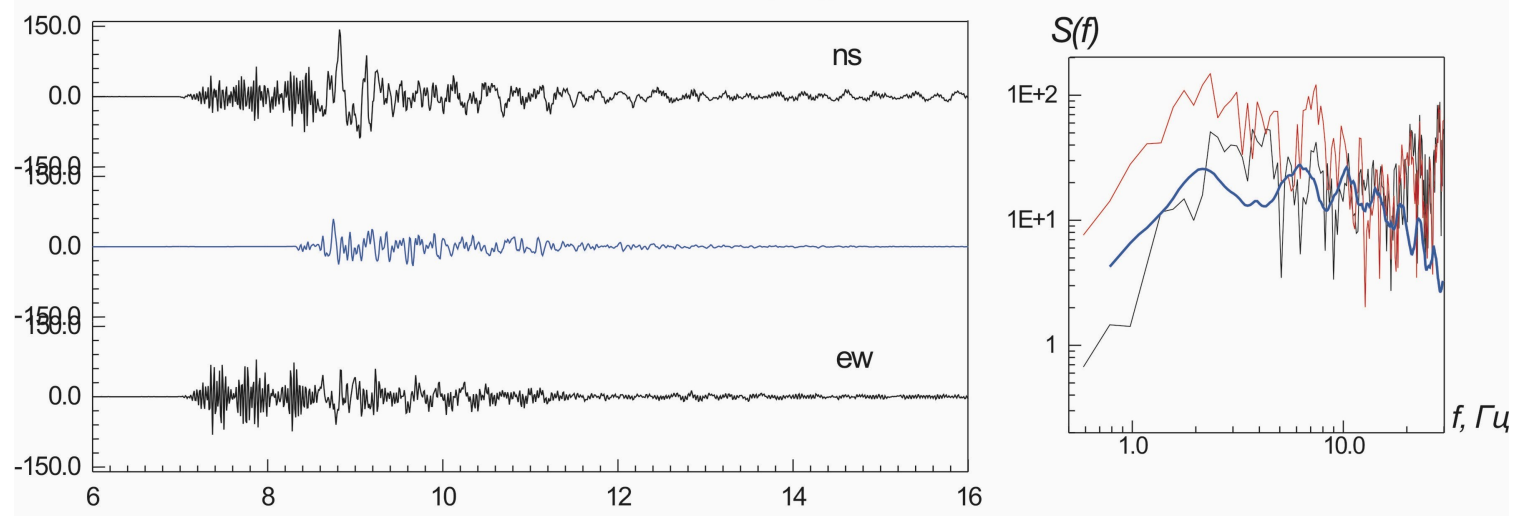

8.12.2010 $\mathrm{M} \sim 4.2$ (4.6), $r \sim 26.6$ км
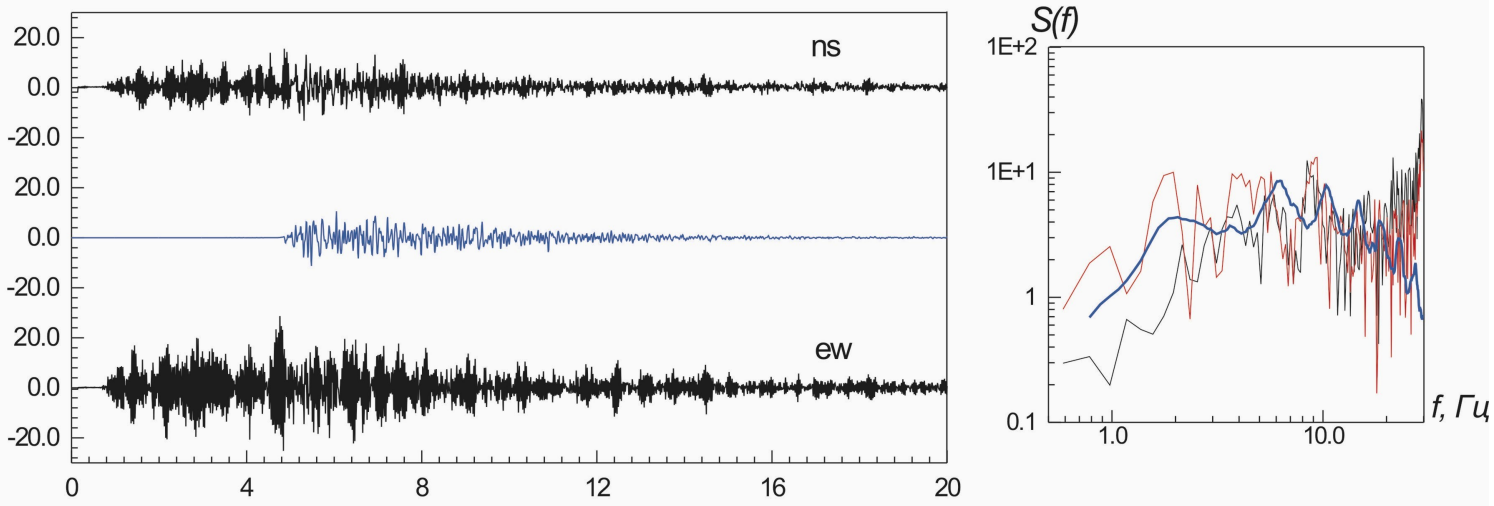

23.08.2007 $\mathrm{M} \sim 4.9(5.1), r \sim 30.1 \mathrm{KM}$
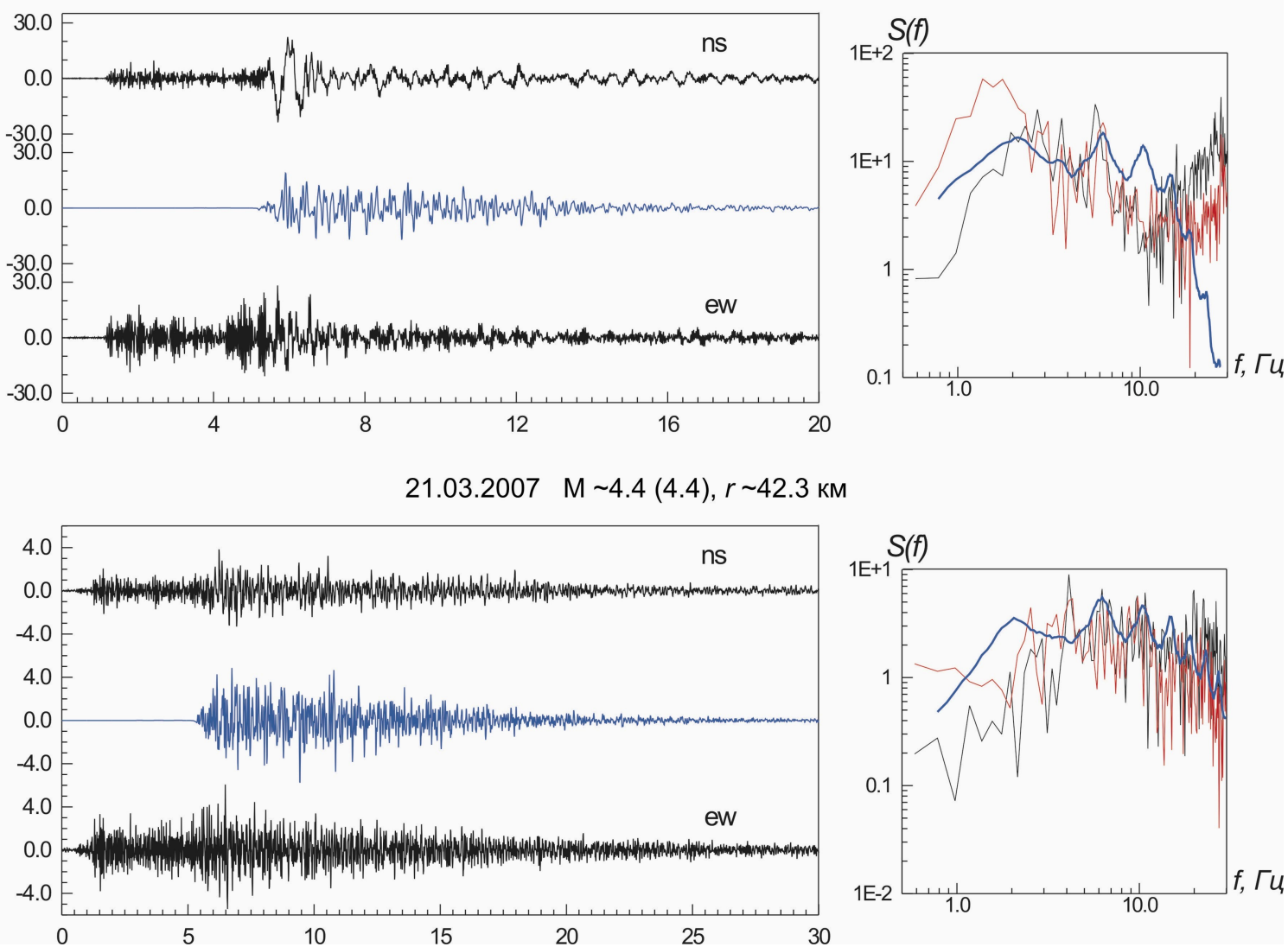
5.04.2007 $\mathrm{M} \sim 5.0(5.2), r \sim 58.6 \mathrm{kM}$
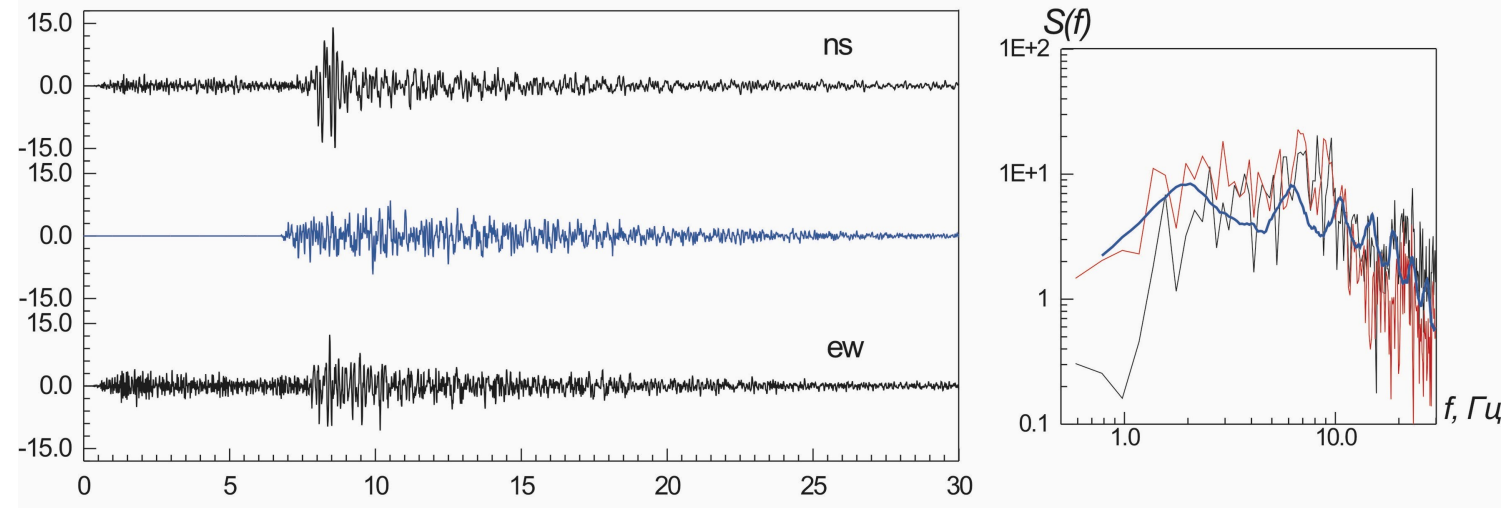

21.08.2005 $\mathrm{M} \sim 4.2(4.5), r \sim 108$ км
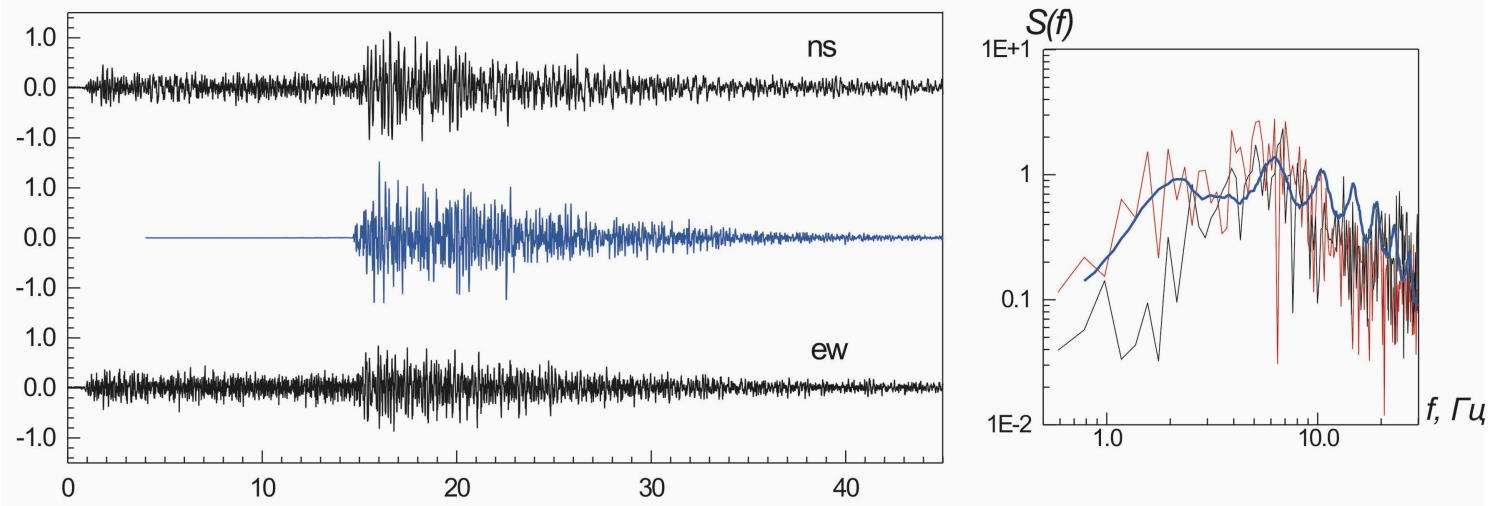

10.06.2009 $\mathrm{M} \sim 4.9(5.0), r \sim 164 \mathrm{KM}$
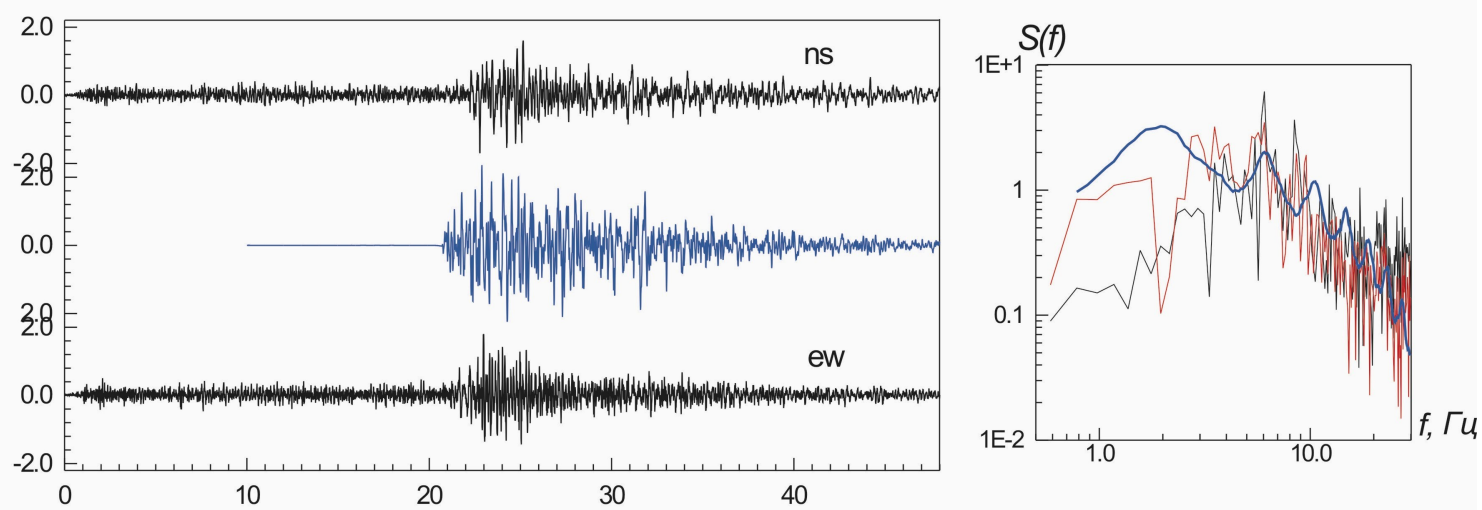

21.01.2007 $\mathrm{M} \sim 4.3(4.6), r \sim 170 \mathrm{kM}$
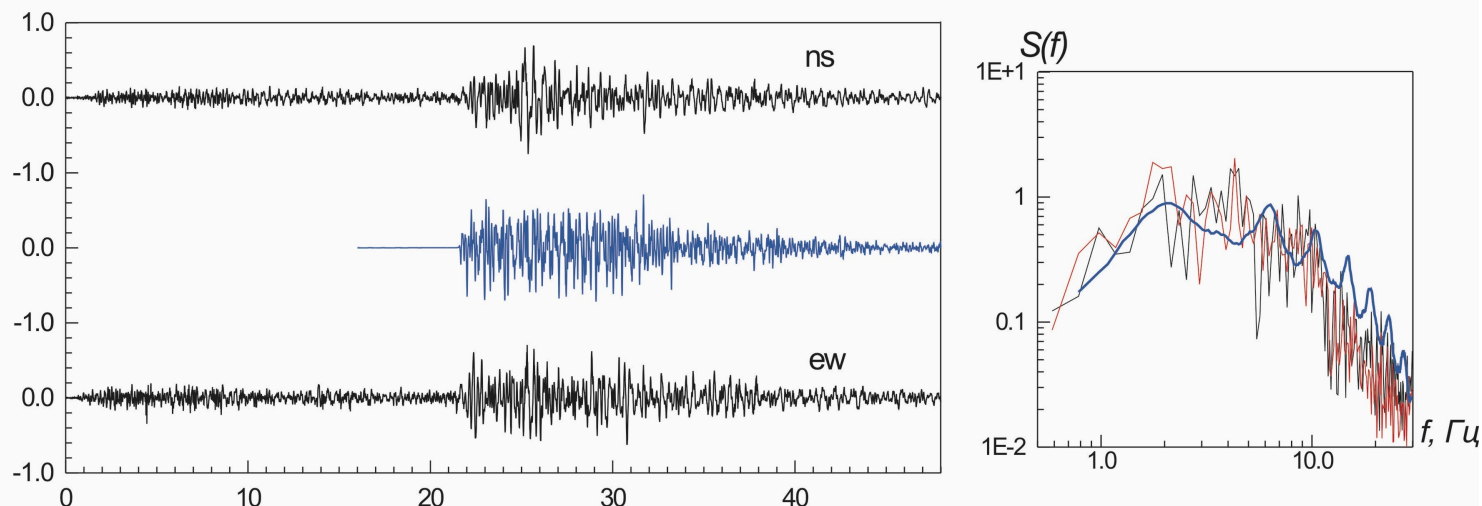
8.02.2006 $\mathrm{M} \sim 4.7$ (4.8), $r \sim 191 \mathrm{kм}$
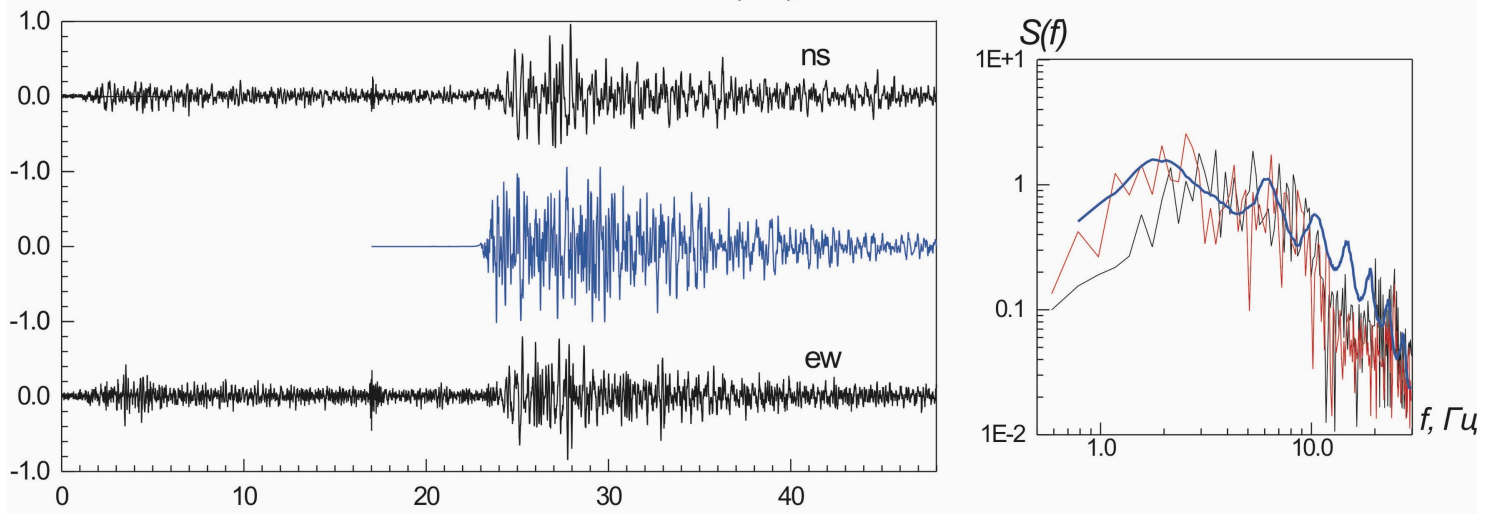

4.07.2007 $\mathrm{M} \sim 5.3$ (5.5), $r \sim 208 \mathrm{kM}$
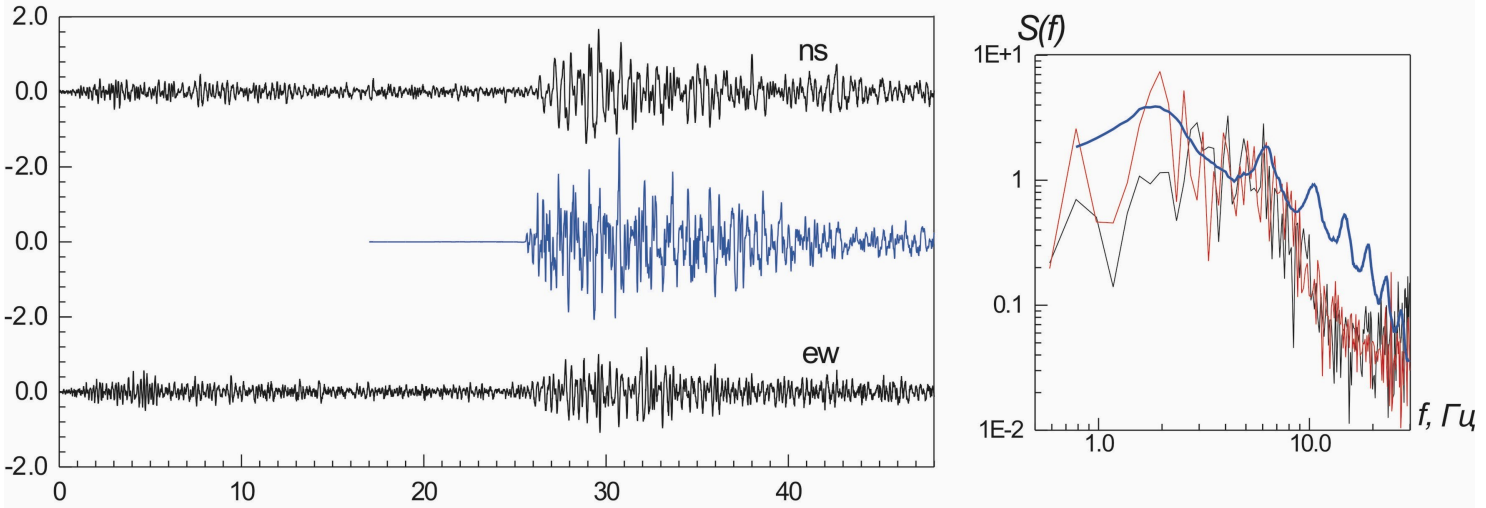

27.08.2007 M 4.8 (4.9), $r \sim 208$ км
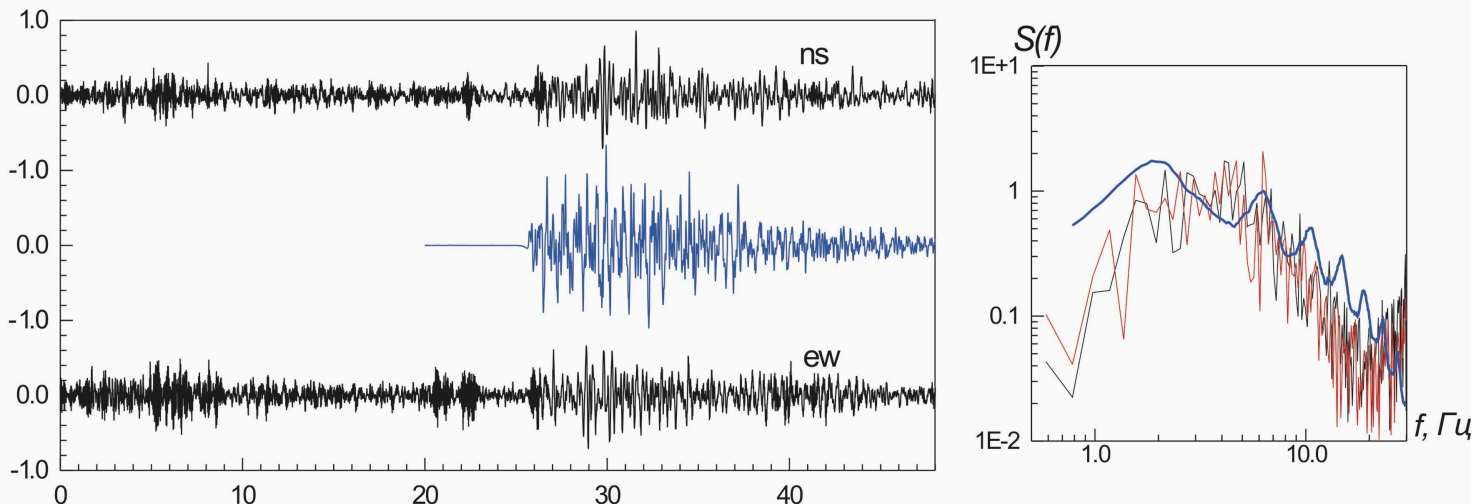

$3.08 .2006 \mathrm{M} \sim 4.5(4.8), r \sim 211 \mathrm{KM}$
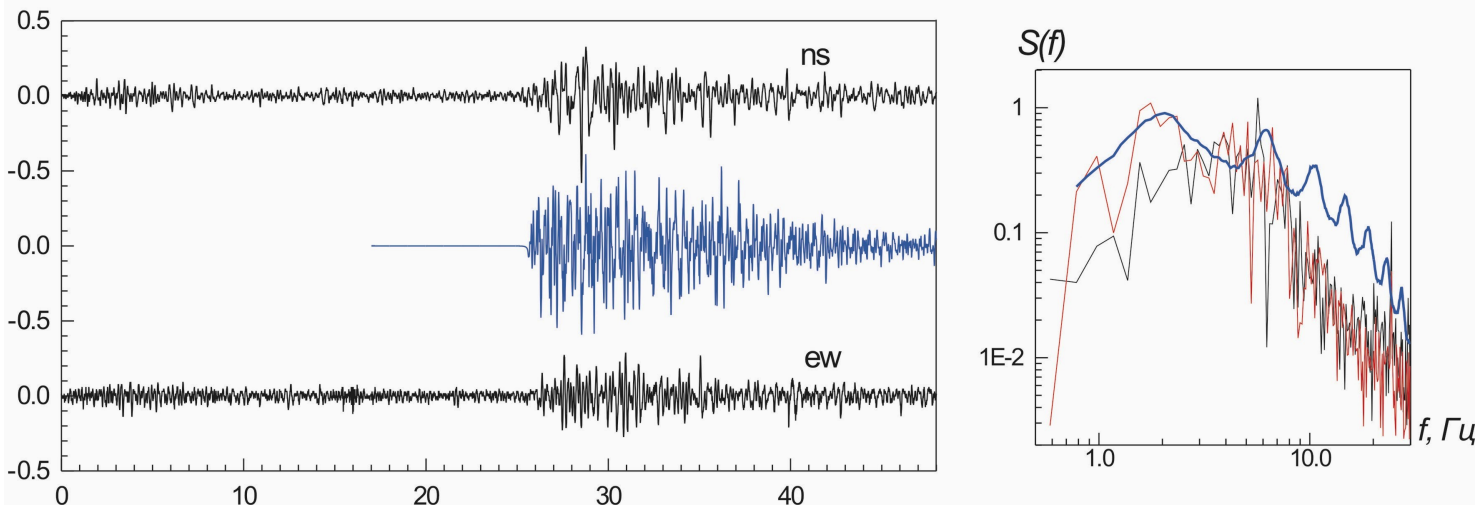
3.08.2006 $\mathrm{M} \sim 4.5(4.7), r \sim 212 \mathrm{kM}$
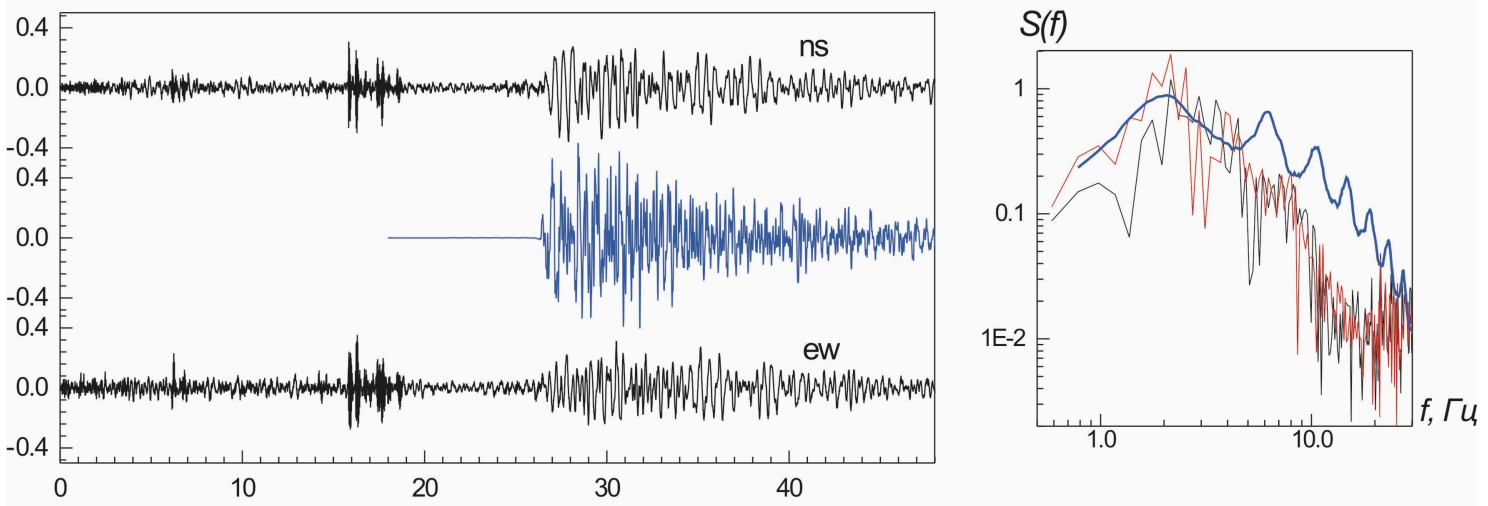

15.12.2006 $\mathrm{M} \sim 4.3(4.7), r \sim 212 \mathrm{kм}$
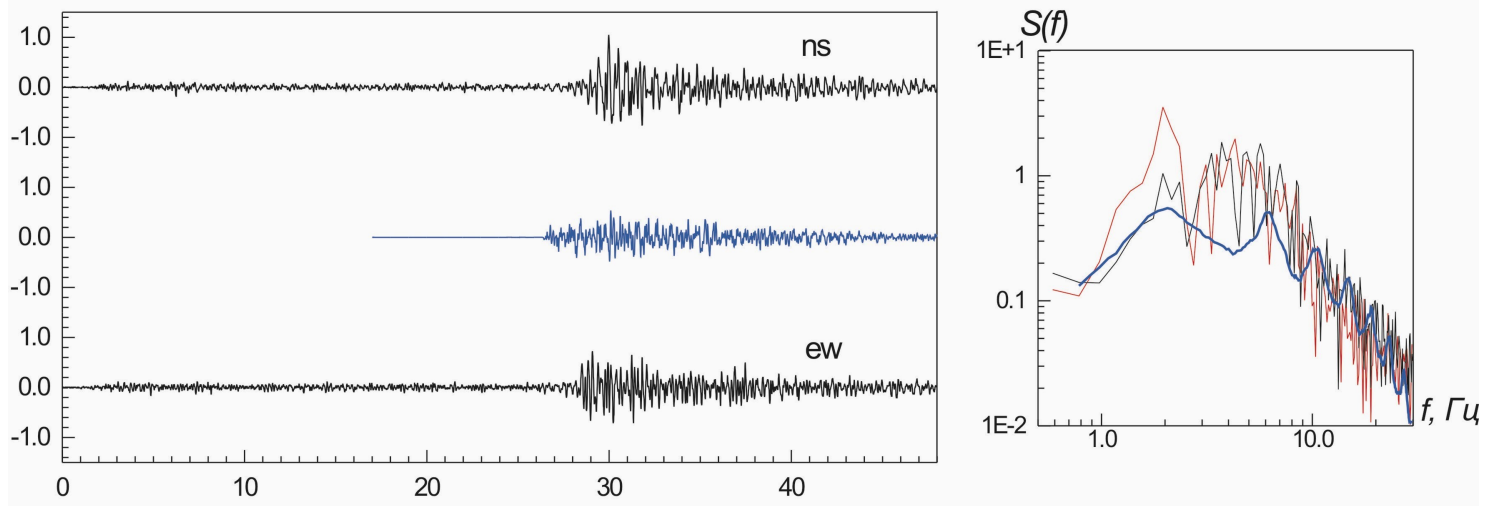

11.12.2006 $\mathrm{M} \sim 4.9(5.0), r \sim 213 \mathrm{kM}$
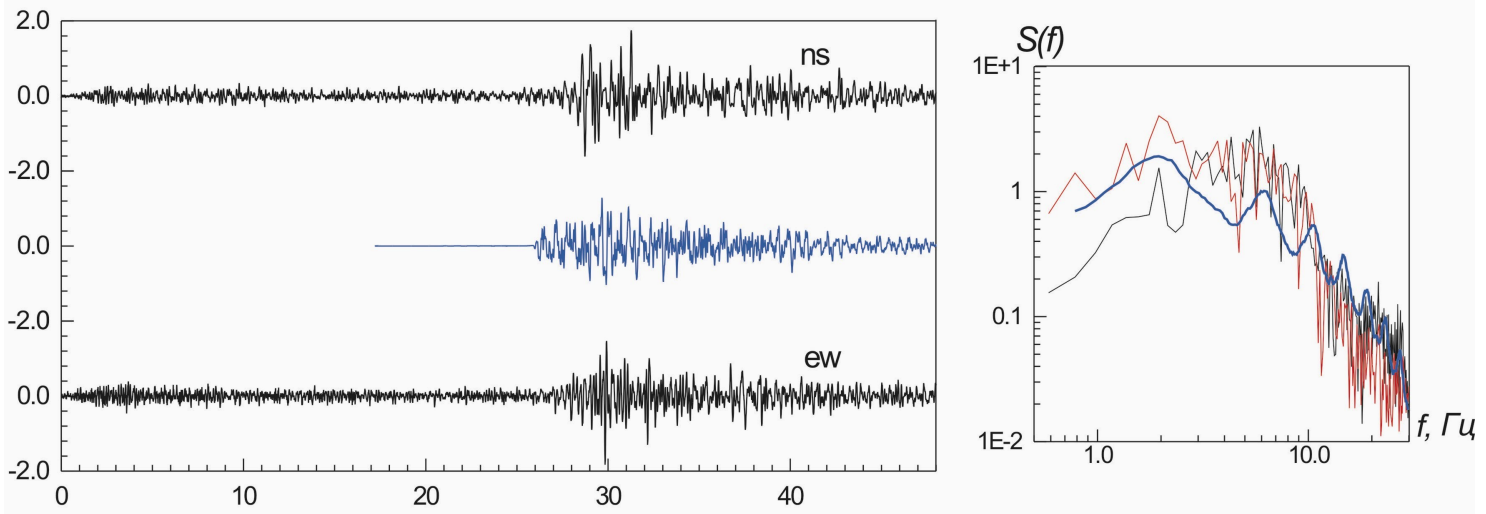

4.12.2006 M 5.2 (5.3), $r \sim 219$ км
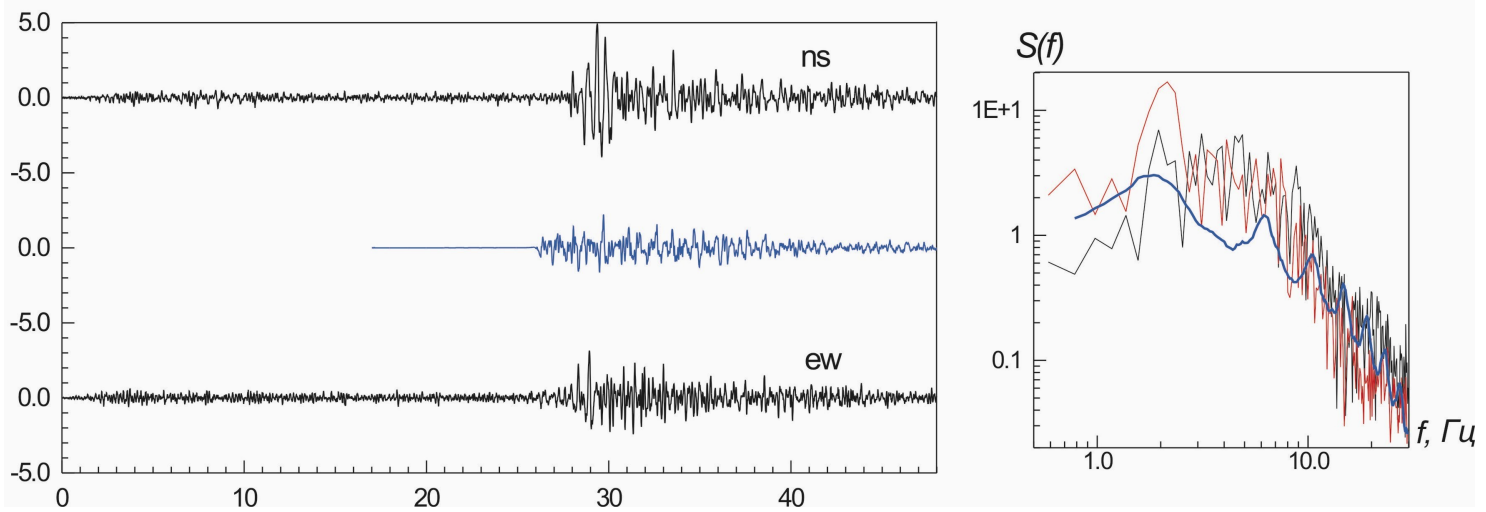

a, cilclo
a. cu/clo
a, culdo

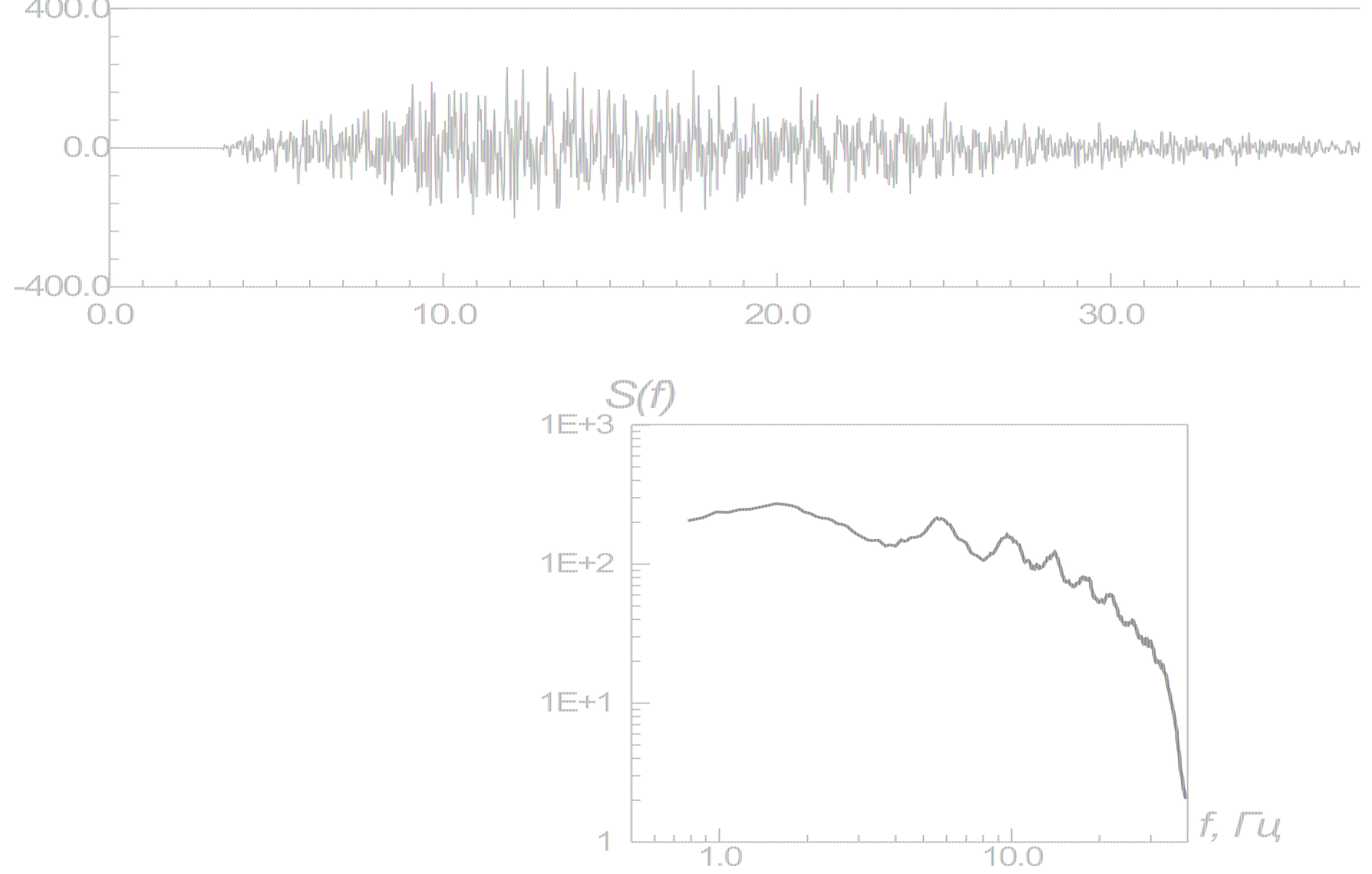

